\title{
Accretion Timescale and Impact History of Mars Deduced from the Isotopic Systematics of Martian Meteorites
}

\author{
Lars E. Borg ${ }^{a *}$, Gregory A. Brennecka ${ }^{a, b}$, Steven J. K. Symes ${ }^{c}$
}

a. Chemical Sciences Division, Lawrence Livermore National Laboratory, 7000 East Avenue L231, Livermore CA 94550 USA. borg5@1lnl.gov (925) 424-5722

b. Institut für Planetologie, Westfälische Wilhelms-Universität Munster, Wilkhekm-Klemm-Str. 10, 48149 Münster Germany brennecka@gmail.com

c. Department of Chemistry, University of Tennessee-Chattanooga, Chattanooga, TN 37403, USA. steven-symes@utc.edu

*Corresponding author 


\begin{abstract}
High precision $\mathrm{Sm}-\mathrm{Nd}$ isotopic analyses have been completed on a suite of 11 martian basaltic meteorites in order to better constrain the age of silicate differentiation on Mars associated with the formation of their mantle sources. These data are used to evaluate the merits and disadvantages of various mathematical approaches that have been employed in previous work on this topic. Ages determined from the $\mathrm{Sm}-\mathrm{Nd}$ isotopic systematics of individual samples are strongly dependent on the assumed $\mathrm{Nd}$ isotopic composition of the bulk planet. This assumption is problematic given differences observed between the $\mathrm{Nd}$ isotopic composition of Earth and chondritic meteorites and the fact that these materials are both commonly used to represent bulk planetary $\mathrm{Nd}$ isotopic compositions. Ages determined from the slope of ${ }^{146} \mathrm{Sm}-{ }^{142} \mathrm{Nd}$ whole rock isochrons are not dependent on the assumed ${ }^{142} \mathrm{Nd} /{ }^{144} \mathrm{Nd}$ ratio of the planet, but require the sample suite to be derived from complementary, contemporaneously-formed reservoirs. In this work, we present a mathematical expression that defines the age of formation of the source regions of such a suite of samples that is based solely on the slope of a ${ }^{143} \mathrm{Nd}-{ }^{142} \mathrm{Nd}$ whole rock isochron and is also is independent of any a priori assumptions regarding the bulk isotopic composition of the planet. This expression is also applicable to mineral isochrons and has been used to successfully calculate ${ }^{143} \mathrm{Nd}-{ }^{142} \mathrm{Nd}$ model crystallization ages of early refractory solids as well as lunar samples. This permits ages to be obtained using only $\mathrm{Nd}$ isotopic measurements without the need for ${ }^{147} \mathrm{Sm} /{ }^{144} \mathrm{Nd}$ isotope dilution determinations. When used in conjunction with high-precision $\mathrm{Nd}$ isotopic measurements completed on martian meteorites this expression yields an age of formation of the martian basaltic meteorite source regions of $4504 \pm 6 \mathrm{Ma}$. Because the Sm-Nd model ages for the formation of martian source regions are commonly interpreted to record the age at which large scale mantle reservoirs formed during planetary differentiation associated with magma ocean solidification, the age determined here implies that magma ocean solidification occurred several tens of millions of years after the beginning of the Solar System. Recent thermal models, however, suggest that Mars-sized bodies cool rapidly in less than $\sim 5 \mathrm{Ma}$ after accretion ceases, even in the presence of a thick atmosphere. Assuming these models are correct, an extended period of accretion is necessary to provide a mechanism to keep portions of the martian mantle partially molten until $4504 \mathrm{Ma}$. Late accretional heating of Mars could either be associated with protracted accretion occurring at a quasi-steady state or alternatively be associated with a late giant impact. If this scenario is correct, then accretion of Mars-sized bodies takes up to $60 \mathrm{Ma}$ and is likely to be contemporaneous with the core formation and possibly the onset of silicate differentiation. This further challenges the concept that isotopic equilibrium is attained during primordial evolution of planets, and may help to account for geochemical evidence implying addition of material into planetary interiors after core formation was completed.
\end{abstract}

\title{
1. INTRODUCTION
}


The planetesimal hypothesis is the favored model for explaining how terrestrial planets formed from the dust and gas that was present in the protoplanetary disk during the birth of our Solar System. This hypothesis describes how dust grains migrating toward the midplane of the disk accrete to form progressively larger planetesimals. Gravitational interactions between planetesimals produce a modest number of relatively large, Mars-sized, planetary embryos, which in turn randomly collide to form the terrestrial planets (Chambers, 2004). Accretion introduces significant quantities of heat into the newly forming terrestrial planets, resulting in broad scale melting and subsequent cooling. Elemental fractionation associated with melting and cooling are thought to produce mineralogically and chemically distinct reservoirs in the core, mantle, and crust resulting in primordial differentiation of the planet. Whereas isotopic dating of the earliest Solar System solids indicates that this process began at $4567 \mathrm{Ma}$ (Amelin et al., 2010; Connelly et al., 2012), its duration is poorly defined.

The timescale of planetary differentiation is constrained by the systematics of daughter isotopes measured in planetary samples that were produced by the decay of short-lived parents that were alive in the earliest stages of Solar System history. Samples from the planet Mars are ideal for this purpose because they demonstrate obvious anomalies in several isotope systems, such as ${ }^{182} \mathrm{Hf}-{ }^{182} \mathrm{~W}$ and ${ }^{146} \mathrm{Sm}-{ }^{142} \mathrm{Nd}$. The martian meteorites are basalts, basaltic cumulates, and ultramafic rocks with large and systematic variations in trace element and isotopic compositions. The basaltic meteorites (shergottites) are the focus of this investigation. The incompatibleelement characteristics of the shergottite source regions, inferred from $\mathrm{Rb}-\mathrm{Sr}$ and $\mathrm{Sm}-\mathrm{Nd}$ isotopic analyses, have been identified and used as a basis to divide the shergottites into subgroups called "enriched", "depleted", and "intermediate" (Borg et al., 2003; Debaille et al., 2007; Symes et al., 2008). The initial Sr and Nd isotopic systematics of the shergottites define mixing lines between incompatible-element enriched and incompatible-element depleted geochemical end-members (Borg et al., 2003; Borg and Draper, 2003) underscoring the close petrogenetic affinity between the various shergottites. The second class of martian meteorites relevant to this investigation is the nakhlites. These meteorites are clinopyroxene cumulates with petrologic and geochemical characteristics that are nearly identical to one another. The nakhlites have ${ }^{182} \mathrm{~W}$ isotopic compositions that are significantly more radiogenic than the shergottites (e.g., Foley et al., 2005), demonstrating that they are derived from a fundamentally different mantle source region than the shergottites.

Geochemical modeling of the shergottite mantle source regions suggests that they could have formed as a result of solidification of a martian magma ocean (Blichert-Toft et al., 1999; Borg et al., 1997; 2003; Borg and Draper, 2003; Elkins-Tanton, 2003), although formation through interaction of mantle and crustal reservoirs has also been proposed (Jones, 1989; Herd et al., 2002). The age of this silicate differentiation event is best determined using the ${ }^{146} \mathrm{Sm}-{ }^{142} \mathrm{Nd}$ system of the shergottites due to the relatively short half-life of ${ }^{146} \mathrm{Sm}$ and the fact that $\mathrm{Sm}$ and $\mathrm{Nd}$ are both refractory lithophile elements. Ages derived from the ${ }^{146} \mathrm{Sm}-{ }^{142} \mathrm{Nd}$ system are based on one of two assumptions. The most precise ages are three-stage Nd evolution model ages for individual samples that assume ${ }^{147} \mathrm{Sm} /{ }^{144} \mathrm{Nd}$ and ${ }^{142} \mathrm{Nd} /{ }^{144} \mathrm{Nd}$ values for bulk Mars (Harper et al., 1995; Borg et al., 1997; Debaille et al., 2007). The ${ }^{142} \mathrm{Nd} /{ }^{144} \mathrm{Nd}$ value for bulk Mars was 
originally assumed to be represented by terrestrial rocks, but most recently has been assumed to be the average value measured for chondritic meteorites. Ages for individual samples are strongly dependent on the assumed ${ }^{142} \mathrm{Nd} /{ }^{144} \mathrm{Nd}$ ratio of bulk Mars, however, and vary by $\sim 50$ Ma depending on whether chondritic or terrestrial values are used in the calculation. This led to the development of whole rock isochron age determinations of martian differentiation based on the range of $\mathrm{Sm}-\mathrm{Nd}$ isotopic compositions displayed by the shergottite meteorite suite. These ages are predicated on geochemical observations implying that the isotopic variability of the martian meteorite suite reflects mixing between complementary, contemporaneously-formed, isotopic reservoirs (Shih et al., 1982; Borg et al., 2003; Foley et al., 2005; Caro et al., 2008). However, previous ages determined using this approach are more imprecise than ages determined on individual samples. This is a reflection of the fact that uncertainty associated with ages defined by a suite of samples includes contributions from both analytical measurement and from scatter exhibited by the sample suite, whereas ages defined by single samples incorporate uncertainty associated only with individual measurements. The most accurate previous estimate of silicate differentiation is probably represented by the average of the published ages reported by (Borg et al., 1997; 2003; Foley et al., 2005; Debaille et al., 2007; Caro et al., 2008) which is $4530 \pm 27 \mathrm{Ma}$ (uncertainty defined by 2 standard deviations).

Tungsten isotopic measurements completed on the martian meteorites have been used to calculate model ages for $\mathrm{Hf} / \mathrm{W}$ fractionation that was originally thought to be associated with core formation on Mars. These models are strongly dependent on the assumed Hf/W ratio for bulk Mars. Furthermore, more recent investigations note that silicate differentiation has the potential to fractionate $\mathrm{Hf}$ from $\mathrm{W}$, whereas late accretion can modify ${ }^{182} \mathrm{~W}$ through the addition of isotopically distinct W (e.g. Mezger et al., 2013). Thus, mechanisms to account for the difference between the ${ }^{182} \mathrm{~W}$ isotopic compositions of shergottites $\left(\varepsilon^{182} \mathrm{~W}=\sim 0.65\right)$ and nakhlites $\left(\varepsilon^{182} \mathrm{~W}=\sim 3.0\right)$ are not well understood, leading Halliday and Kleine (2006) to suggest that caution should be used when interpreting $\mathrm{W}$ ages calculated from martian meteorite data. Nevertheless, evidence for fractionation of $\mathrm{Hf}$ from $\mathrm{W}$ in martian meteorites is irrefutable and this system still provides the best constraint for the timing of martian core formation. Numerous ages of core formation have been calculated based on a range of model parameters. The most conservative estimate of the age of martian core formation is probably the average of these ages which is $4559 \pm 8 \mathrm{Ma}$ (average \pm 2 standard deviations of ages reported by Kleine et al., 2004; 2009; Foley et al., 2005; Halliday and Kleine, 2006; Nimmo and Kleine, 2007; Dauphas and Pourmand, 2011). This calculated Hf-W age of core formation is within uncertainty of the average $\mathrm{Sm}-\mathrm{Nd}$ age of silicate differentiation of $4530 \pm 27 \mathrm{Ma}$ inferred from the shergottites indicating that the duration of martian planetary differentiation could have been as short as 10 Ma or as long as $64 \mathrm{Ma}$ after formation of the first Solar System solids. A short time interval between core formation and silicate (crust/mantle) differentiation would imply the martian core and mantle formed more or less simultaneously, whereas a long time interval would imply that the planet had a more protracted accretion and differentiation history. In order to more accurately define the duration of planetary accretion and differentiation on Mars, we have completed high-precision $\mathrm{Sm}-\mathrm{Nd}$ isotopic measurements on a suite of shergottites and used 
these as a basis to rigorously evaluate and further develop various approaches to constrain the differentiation age of the shergottite source regions.

\section{METHODS}

High precision ${ }^{147} \mathrm{Sm} /{ }^{144} \mathrm{Nd}-{ }^{143} \mathrm{Nd} /{ }^{144} \mathrm{Nd}-{ }^{142} \mathrm{Nd} /{ }^{144} \mathrm{Nd}$ and ${ }^{87} \mathrm{Rb} /{ }^{86} \mathrm{Sr}-{ }^{87} \mathrm{Sr} /{ }^{86} \mathrm{Sr}$ isotopic measurements have been completed on 10 shergottites exhibiting trace element characteristics indicative of derivation from the observed range of enriched, intermediate, depleted source regions. The high precision measurements were completed on 5 shergottites with enriched source regions (Los Angeles, NWA1068, Dho378, NWA4468, and NWA4878), 3 with depleted source regions (Tissint, DaG476, and SaU005), and 2 of intermediate composition (EET79001A and NWA480). An additional relatively small aliquot of the depleted shergottite Dhofar 019 has been analyzed for ${ }^{147} \mathrm{Sm} /{ }^{144} \mathrm{Nd}-{ }^{143} \mathrm{Nd} /{ }^{144} \mathrm{Nd}$ and ${ }^{87} \mathrm{Rb} /{ }^{86} \mathrm{Sr}-{ }^{87} \mathrm{Sr} /{ }^{86} \mathrm{Sr}$ only.

A detailed discussion of sample digestions and mass spectrometry techniques is presented in the supplement. In brief, fractions of martian meteorites were dissolved after washing in water and $0.1 \mathrm{M}$ acetic acid in a Class 100 laboratory at Lawrence Livermore National Laboratory (LLNL). Small fractions were spiked using mixed ${ }^{149} \mathrm{Sm}-{ }^{150} \mathrm{Nd}$ tracer and ${ }^{87} \mathrm{Rb}-{ }^{84} \mathrm{Sr}$ tracers to obtain whole rock ${ }^{147} \mathrm{Sm} /{ }^{144} \mathrm{Nd}$ and ${ }^{87} \mathrm{Rb} /{ }^{86} \mathrm{Sr}$ values. These concentration data are presented in Table 1. Both spiked and unspiked samples were purified using a combination of ion-exchange chromatographic procedures. Rubidium, strontium, and rare earth elements (REE) were purified using $2 \mathrm{~N} \mathrm{HCl}, 2 \mathrm{~N} \mathrm{HNO}_{3}$, and $6 \mathrm{~N} \mathrm{HCl}$ acids and $\mathrm{AG} 50 \mathrm{~W}-\mathrm{X} 8$ 200-400 mesh resin in quartz columns. Strontium was further purified using Sr-Spec resin in $100 \mu \mathrm{L}$ Teflon columns with $1 \mathrm{~N} \mathrm{HNO}_{3}$ and $\mathrm{H}_{2} \mathrm{O}$. The $\mathrm{Sm}$ and $\mathrm{Nd}$ were separated in pressurized quartz columns using $0.2 \mathrm{M}$ alpha-hydroxyisobutyric acid buffered to $\mathrm{pH}=4.4$ and AG 50W-X8 200-400 mesh resin converted to $\mathrm{NH}_{4}$ form. Total procedural blanks including digestions were $\mathrm{Rb}=9 \mathrm{pg}, \mathrm{Sr}=23$ $\mathrm{pg}, \mathrm{Sm}=6 \mathrm{pg}$ and $\mathrm{Nd}=17 \mathrm{pg}$ for the isotope dilution measurements.

Samarium and neodymium analyzed for isotope composition were purified from the matrix with $2 \mathrm{~mL}$ BioRad columns filled with AG 50W-X8 200-400 mesh resin using 2N and 6N $\mathrm{HCl}$. Several BioRad columns were needed for some samples because of their large masses. The REE cuts from the BioRad columns were further purified with $150 \mu \mathrm{L}$ Teflon columns containing Eichron RE resin (50-100 mesh) using $3 \mathrm{~N}$ and $0.05 \mathrm{~N} \mathrm{HNO}_{3}$. Samarium and neodymium were separated using the pressurized quartz columns using $0.2 \mathrm{M}$ alphahydroxyisobutyric acid procedure described above. Neodymium was put through this procedure twice to remove Ce. Total procedural blanks for $\mathrm{Nd}$ and $\mathrm{Sm}$ ranged from 20 to $44 \mathrm{pg}$, and from 13 to $28 \mathrm{pg}$, respectively for the isotope composition measurements depending on how many 2 $\mathrm{mL}$ BioRad columns were needed for the initial purification step.

Isotopic analyses were obtained using a ThermoScientific Triton thermal ionization mass spectrometer at LLNL. Neodymium and samarium were loaded in $2 \mathrm{~N} \mathrm{HCl}$ onto zone refined Re double filaments. High precision ${ }^{142} \mathrm{Nd} /{ }^{144} \mathrm{Nd}$ ratios were obtained through multi-dynamic analyses at high intensity (up to $4.9 \times 10^{-11}$ amperes ${ }^{144} \mathrm{Nd}$ ) and long duration (up to 13.5 hours) 
on the unspiked $\mathrm{Nd}$ fractions. Neodymium was corrected for instrumental mass fractionation using ${ }^{146} \mathrm{Nd} /{ }^{144} \mathrm{Nd}=0.7219$. Isobaric interferences on $\mathrm{Nd}$ were monitored using ${ }^{140} \mathrm{Ce}$ and ${ }^{149} \mathrm{Sm}$. Cerium corrections ranged from 0 to $7.1 \mathrm{ppm}$, whereas $\mathrm{Sm}$ interference corrections were not needed. Average values determined on $\mathrm{Nd}$ and $\mathrm{Sm}$ isotopic standards are presented in Table 2. Replicate ${ }^{142} \mathrm{Nd} /{ }^{144} \mathrm{Nd}$ analyses completed on shergottites and terrestrial standards during the course of this investigation agreed within $3 \mathrm{ppm}$. The maximum difference between four samples analyzed by both Debaille et al. (2007) and in this investigation was also $3 \mathrm{ppm}$. Neodymium isotope dilution measurements were completed using static acquisition in which 200 eightsecond integrations were collected. The isotopic composition of Sm was obtained from unspiked fractions of the samples using a static acquisition routine consisting of 200 eight-second integrations. The intensity of these runs ranged from 1.0 to $1.8 \times 10^{-11}$ amperes of ${ }^{149} \mathrm{Sm}$. Samarium was corrected for mass fractionation assuming ${ }^{147} \mathrm{Sm} /{ }^{152} \mathrm{Sm}=0.56081$. Isobaric interferences for Sm were monitored using ${ }^{155} \mathrm{Gd}$ and ${ }^{146} \mathrm{Nd}$ and were less than $2 \mathrm{ppm}$. The Sm isotopic data obtained during this investigation is presented in Table 3.

Rubidium was loaded on single zone refined Re filaments in $2 \mathrm{~N} \mathrm{HCl}$ with a $99.999 \%$ pure $\mathrm{Ta}_{2} \mathrm{O}_{5}$ emitter suspended in $0.5 \mathrm{M} \mathrm{H}_{3} \mathrm{PO}_{4}$. Fractionation was corrected using runs of NBS984 completed during the course of the investigation. Strontium was also loaded on single zone refined Re filaments in $2 \mathrm{~N} \mathrm{HCl}$ with the $\mathrm{Ta}_{2} \mathrm{O}_{5}$ emitter and run at 3 to $6 \times 10^{-11}$ amps ${ }^{88} \mathrm{Sr}$ for 200 ratios of 16 second integrations. Fractionation was corrected assuming ${ }^{86} \mathrm{Sr} /{ }^{88} \mathrm{Sr}=0.1194$. Although ${ }^{85} \mathrm{Rb}$ was monitored during the analyses, it was not detected during $\mathrm{Sr}$ measurements. Strontium isotopic compositions of samples and standards completed during the course of this investigation are presented in Table 2 .

\section{RESULTS}

\subsection{Samarium isotopic compositions}

The Sm isotopic composition of the shergottites was determined in order to assess if they have been modified by the capture of thermal neutrons on the martian surface (Table 3). This phenomenon is well known on the Moon where galactic cosmic rays produce thermal neutrons that are captured by isotopes, such as ${ }^{149} \mathrm{Sm}$, that have exceedingly large neutron capture cross sections (Russ, 1972). Such modification of the ${ }^{149} \mathrm{Sm}$ abundance of a sample will affect the ${ }^{147} \mathrm{Sm} /{ }^{144} \mathrm{Nd}$ ratio if undetected. An excessively large thermal neutron fluence, such as is observed on the Moon, can even affect ${ }^{142} \mathrm{Nd} /{ }^{144} \mathrm{Nd}$ ratios of the samples (e.g., Nyquist et al., 1995). Our data indicate, however, that the Sm isotopic compositions of the shergottites are within analytical uncertainty of values obtained on terrestrial rock and isotopic standards (Table 3 and supplement). Thus, the ${ }^{149} \mathrm{Sm}$ data suggest that levels of thermal neutron radiation have been low near the martian surface over the past $\sim 600 \mathrm{Ma}$ so that ${ }^{147} \mathrm{Sm} /{ }^{144} \mathrm{Nd}$ and ${ }^{142} \mathrm{Nd} /{ }^{144} \mathrm{Nd}$ ratios determined on the shergottites require no corrections. 


\subsection{Neodymium and strontium isotopic compositions}

The ${ }^{87} \mathrm{Rb} /{ }^{86} \mathrm{Sr}$ and ${ }^{147} \mathrm{Sm} /{ }^{144} \mathrm{Nd}$ ratios of the shergottites have been determined using the isotope dilution technique and are presented in Table 1 , whereas the ${ }^{87} \mathrm{Sr} /{ }^{86} \mathrm{Sr},{ }^{143} \mathrm{Nd} /{ }^{144} \mathrm{Nd}$, and ${ }^{142} \mathrm{Nd} /{ }^{144} \mathrm{Nd}$ isotopic compositions of the shergottites are presented in Table 2 . The isotopic compositions of terrestrial rock and mass spectrometry standards are also presented in Table 2. The supplement provides all $\mathrm{Sm}$ and $\mathrm{Nd}$ isotopic composition measurements completed on all samples, isotopic standards, and terrestrial rock standards analyzed during this investigation. In general, the shergottite data are similar to that previously reported for similar martian meteorites (see summary in Nyquist et al., 2001; as well as Borg et al., 2003; Foley et al., 2005; Debaille et al., 2007; Caro et al., 2008). The ${ }^{87} \mathrm{Rb} /{ }^{86} \mathrm{Sr}$ ratios determined for the suite of shergottites is highly variable ranging from 0.006 to 0.35 . Although the range of ${ }^{87} \mathrm{Rb} /{ }^{86} \mathrm{Sr}$ generally correlates with shergottite subgroup (depleted, intermediate, enriched) there is some overlap. The ${ }^{147} \mathrm{Sm} /{ }^{144} \mathrm{Nd}$ ratios measured for this suite of shergottites are also typical, ranging from 0.23 to 0.51, and mostly correlating with shergottite subgroup. The depleted subgroup, however, demonstrates a large range of ${ }^{147} \mathrm{Sm} /{ }^{144} \mathrm{Nd}$ ratios from 0.38 to 0.51 overlapping the range defined by the intermediate group. As expected the $\mathrm{Sr}$ and $\mathrm{Nd}$ isotopic compositions correlate well with the shergottite subgroup because they are used to define the subgroups. The depleted shergottites have ${ }^{87} \mathrm{Sr} /{ }^{86} \mathrm{Sr}=0.701-0.708,{ }^{143} \mathrm{Nd} /{ }^{144} \mathrm{Nd}=0.5151-0.5155$, and ${ }^{142} \mathrm{Nd} /{ }^{144} \mathrm{Nd}=$ $1.141911-1.141920\left(\varepsilon^{142} \mathrm{Nd}=+0.57\right.$ to +0.72$)$. The intermediate shergottites have ${ }^{87} \mathrm{Sr} /{ }^{86} \mathrm{Sr}=$ $0.710-0.713,{ }^{143} \mathrm{Nd} /{ }^{144} \mathrm{Nd}=0.5134-0.5137$, and ${ }^{142} \mathrm{Nd} /{ }^{144} \mathrm{Nd}=1.141854-1.141863\left(\varepsilon^{142} \mathrm{Nd}=\right.$ +0.15 to +0.23$)$. The isotopic compositions of the enriched shergottites are remarkably consistent with ${ }^{87} \mathrm{Sr} /{ }^{86} \mathrm{Sr}=0.718-0.723,{ }^{143} \mathrm{Nd} /{ }^{144} \mathrm{Nd}=0.51231-0.51235$, and ${ }^{142} \mathrm{Nd} /{ }^{144} \mathrm{Nd}=$ 1.141813-1.141819 $\left(\varepsilon^{142} \mathrm{Nd}=-0.21\right.$ to -0.16$)$. The $\mathrm{Rb}-\mathrm{Sr}$ isotopic systematics of the shergottites analyzed in this study are quite variable reflecting both compositional differences inherited from their source regions and addition of terrestrial $\mathrm{Sr}$ during weathering in the desert localities where many of these samples were found. The desert meteorites display $\mathrm{Sm}-\mathrm{Nd}$ isotopic systematics that are essentially identical to those determined from non-desert meteorites indicating that the $\mathrm{Sm}-\mathrm{Nd}$ isotopic system has not been affected by weathering.

\section{MODEL AgE CALCULATIONS}

In this section, mathematical expressions used to obtain model ${ }^{146} \mathrm{Sm}^{-142} \mathrm{Nd}$ and ${ }^{143} \mathrm{Nd}-$

${ }^{142} \mathrm{Nd}$ ages are discussed. The terms source and reservoir are used extensively throughout this discussion and warrant a clear definition to avoid confusion. A source, considered in the context of the isotopic systematics discussed here, refers to the rocks from which the shergottites are derived by partial melting. The sources contribute $\mathrm{Sm}, \mathrm{Nd}, \mathrm{Rb}$, and $\mathrm{Sr}$ to shergottite magmas. In 
contrast, a reservoir is a large scale feature that formed during primordial differentiation of the planet and has remained isolated. Potential examples of reservoirs are incompatible-element depleted mantle cumulates, incompatible-element enriched mantle materials, as well as crustal lithologies. Thus, the source of an individual meteorite may contain components derived from several reservoirs.

\subsection{Samarium-neodymium ages}

\subsection{1 ${ }^{147} \mathrm{Sm} /{ }^{144} \mathrm{Nd}$ of basalt source regions}

In this section we present three approaches to calculate model ages for the formation of depleted and enriched shergottite source regions using the Sm-Nd isotopic system are presented. All three approached are based on the simplifying, and commonly adopted, assumption that after accretion Mars was initially homogeneous and undifferentiated. Subsequent melting associated with accretional heating and radioactive decay resulted in differentiation of the primordial body into large scale silicate reservoirs with fractionated elemental abundances. These reservoirs evolved through time until they were melted to produce the shergottite magmas. Thus, the ages of formation of the shergottite source regions calculated in this manner are commonly interpreted to record the time of primordial silicate differentiation on Mars (E.g., Harper et al., 1995; Borg et al., 1997; 2003; Debaille et al., 2007; Caro et al., 2008).

The $\mathrm{Sm}-\mathrm{Nd}$ isotopic system provides a powerful tool with which to constrain the timing of silicate differentiation. This stems from the fact that it comprises of two decay chains. The first is ${ }^{147} \mathrm{Sm} \rightarrow{ }^{143} \mathrm{Nd}$ with a half-life of $106 \mathrm{Ga}$. This decay chain provides a record of the longterm, time-integrated, elemental fractionation of $\mathrm{Sm} / \mathrm{Nd}$ that occurred over the entire history of the planet beginning at $4567 \mathrm{Ma}$ until the present. This system is therefore ideal to estimate the average ${ }^{147} \mathrm{Sm} /{ }^{144} \mathrm{Nd}$ ratio of individual meteorite source regions. The second decay chain is ${ }^{146} \mathrm{Sm} \rightarrow{ }^{142} \mathrm{Nd}$. Although the half-life for this system was recently determined to be $68 \mathrm{Ma}$ (Kinoshita et al., 2012), the traditional half-life of $103 \pm 5$ Ma (Friedman et al., 1966; Meissner et al., 1987) appears to best reproduce the absolute ages of many planetary samples (Borg et al., 2014; Marks et al., 2014a). Therefore, the 103 Ma half-life is used in the calculations presented here. The relatively short half-life of ${ }^{146} \mathrm{Sm}$ allows this decay chain to record the timing of geologic processes that fractionated Sm from $\mathrm{Nd}$ in the earliest stages of planetary history. When both $\mathrm{Sm}-\mathrm{Nd}$ decay chains are used together in an iterative fashion, they can define the ${ }^{147} \mathrm{Sm} /{ }^{144} \mathrm{Nd},{ }^{143} \mathrm{Nd} /{ }^{144} \mathrm{Nd}$, and ${ }^{142} \mathrm{Nd} /{ }^{144} \mathrm{Nd}$ ratios of planetary-scale reservoirs and the age of differentiation of these reservoirs.

There are three ways to calculate Sm-Nd model ages for the formation of the shergottite source regions using the measured $\mathrm{Sm}-\mathrm{Nd}$ isotopic compositions of bulk samples. These model age calculations are discussed separately in the following sections. All three approaches used to 
determine the age of shergottite source formation require the present-day ${ }^{147} \mathrm{Sm} /{ }^{144} \mathrm{Nd}$ ratios of the shergottite source regions to be known. This can be estimated in two ways. In the first, the ${ }^{147} \mathrm{Sm} /{ }^{144} \mathrm{Nd}$ ratio of the bulk rock is used as a proxy for the ${ }^{147} \mathrm{Sm} /{ }^{144} \mathrm{Nd}$ of its source region. This assumes that $\mathrm{Sm}$ is minimally fractionated from $\mathrm{Nd}$ during the partial melting events that produced the basaltic parental melts and that the accumulation of mineral phases in the basalts has not changed their $\mathrm{Sm} / \mathrm{Nd}$ ratios. It has been demonstrated, however, that these assumptions may not be valid for Mars (Borg et al., 1997; 2003; Debaille et al., 2007; 2008). The ${ }^{147} \mathrm{Sm} /{ }^{144} \mathrm{Nd}$ ratios of the shergottites indicate that they are derived from more depleted source regions than is suggested by their ${ }^{143} \mathrm{Nd} /{ }^{144} \mathrm{Nd}$ ratios. For example, the ${ }^{147} \mathrm{Sm} /{ }^{144} \mathrm{Nd}$ ratios of the shergottites from the enriched subgroup are significantly higher (0.23-0.25) than the chondritic value of 0.1967 , yet the meteorites have initial $\varepsilon^{143} \mathrm{Nd}$ values that range from -6 to -8 (Tables 12). Similar relationships between whole rock and calculated source ${ }^{147} \mathrm{Sm} /{ }^{144} \mathrm{Nd}$ ratios exist for the two other shergottite subgroups. Estimating the ${ }^{147} \mathrm{Sm} /{ }^{144} \mathrm{Nd}$ of the shergottite source region from the bulk rock ${ }^{147} \mathrm{Sm} /{ }^{144} \mathrm{Nd}$ values is therefore unlikely to be accurate.

The second way to calculate the present-day ${ }^{147} \mathrm{Sm} /{ }^{144} \mathrm{Nd}$ ratio of shergottite sources was published by Nyquist et al. (1995) and is presented in Equation 1. The equation uses the age, as well as the ${ }^{147} \mathrm{Sm} /{ }^{144} \mathrm{Nd}$ and ${ }^{143} \mathrm{Nd} /{ }^{144} \mathrm{Nd}$ ratios of the basalts, and assumes that the $\mathrm{Nd}$ isotopic systematics reflect growth in three stages of evolution (Figure 1). The first stage of growth occurs in an undifferentiated reservoir that is assumed to have present-day ${ }^{147} \mathrm{Sm} /{ }^{144} \mathrm{Nd}=0.1967$ and ${ }^{143} \mathrm{Nd} /{ }^{144} \mathrm{Nd}=0.512638$ (Jacobsen and Wasserburg, 1980). The second stage occurs in the differentiated reservoir that formed at $\mathrm{T}_{1}$ (calculated below to be $4504 \mathrm{Ma}$ ) until the age of eruption (i.e., crystallization) of the samples. The final stage occurs in the rock itself until the present time. Table 4 presents a summary of the variables used in the following equations.

(Eq. 1)

$$
\left(\frac{{ }^{147} S m}{{ }^{144} N d}\right)^{S}=\frac{\left[\left(\frac{{ }^{143} N d}{{ }^{144} N d}\right)^{M 3}-\left(\frac{{ }^{143} N d}{{ }^{144} N d}\right)^{S S I}-\left(\frac{{ }^{147} S m}{{ }^{144} N d}\right)^{C h}\left(e^{\lambda^{147} T_{0}}-e^{\lambda^{147} T_{1}}\right)-\left(\frac{{ }^{147} S m}{{ }^{144} N d}\right)^{M 1}\left(e^{\lambda^{147} T_{2}}-1\right)\right]}{\left(e^{\lambda^{147} T_{1}}-e^{\lambda^{147} T_{2}}\right)}
$$

The present-day ${ }^{147} \mathrm{Sm} /{ }^{144} \mathrm{Nd}$ ratios of the mantle source regions are calculated assuming they also evolved in three-stages of evolution and are therefore analogous to the model ages of the shergottite sources calculated here. The ${ }^{147} \mathrm{Sm} /{ }^{144} \mathrm{Nd}$ ratios of the shergottite sources, however, are also dependent on the age at which they formed (i.e. differentiated). Thus, the ${ }^{147} \mathrm{Sm} /{ }^{144} \mathrm{Nd}$ and the age of the source must be derived simultaneously (see equations $2,3,4 \mathrm{~b}$, and $4 \mathrm{c}$ below). 


\subsubsection{Three stage model age for individual samples}

The simplest approach to determine the age of formation of a planetary basalt source region is to calculate three-stage $\mathrm{Nd}$ model ages on single samples using Equations 1 and 2 from the ${ }^{147} \mathrm{Sm} /{ }^{144} \mathrm{Nd}$ and ${ }^{142} \mathrm{Nd} /{ }^{144} \mathrm{Nd}$ ratios of the source region of the basaltic sample today. This is a commonly used technique to define basalt source model ages and has been widely adopted for systems with only one radiogenic parent-daughter pair (e.g., $\left.{ }^{182} \mathrm{Hf}-{ }^{182} \mathrm{~W}\right)$. It was also adopted when ${ }^{142} \mathrm{Nd}$ isotopic measurements were first completed on bulk martian samples (Harper et al., 1995; Borg et al., 1997; Deabille et al., 2007). Thus, it is not surprising that Equation 2 describing three stage $\mathrm{Nd}$ model age calculations for individual samples is structurally identical to the equation used for other short-lived chronometers, such as Hf-W model ages (e.g., Kleine et al., 2009). Like many other model ages derived from short-lived isotopic systems, Equation 2 is referenced to the age of CAIs of $4567 \mathrm{Ma}$ (Amelin et al., 2010; Connelly et al., 2012).

(Eq. 2)

$$
\text { Age ofdifferentiation }\left(T_{1}\right)=T_{0}-\left(\frac{1}{\lambda^{146}}\right) \ln \left\{\left(\frac{{ }^{146} S m}{{ }^{444} S m}\right)^{S S I} \frac{\left(\frac{147 S m}{{ }^{144} N d}\right)^{S}\left(\frac{144 S m}{{ }^{147} S m}\right)^{S t d}-\left(\frac{147 s m}{{ }^{144} N d}\right)^{C h}\left(\frac{144 S m}{147}\right)^{S t d}}{\left(\frac{142 N d}{142}\right)^{M 2}-\left(\frac{142 N d}{{ }^{144} N d}\right)^{B}}\right\}
$$

Ages calculated using Equation 2 must incorporate the $\mathrm{Sm} / \mathrm{Nd}$ ratio of the shergottite source regions (expressed in equation 2 as $\left(\frac{{ }^{147} \mathrm{Sm}}{{ }^{144} \mathrm{Nd}}\right)^{S}$ ), as well as an estimate of the $\mathrm{Nd}$ isotopic composition of the bulk planet (expressed as $\left(\frac{142 N d}{144}\right)^{B}$ ). The advantage of the $\mathrm{Sm}-\mathrm{Nd}$ system over other short-lived chronometers is that the $\mathrm{Sm} / \mathrm{Nd}$ ratio of the shergottite source regions can be determined from ${ }^{143} \mathrm{Nd} /{ }^{144} \mathrm{Nd}$ isotopic measurements of the samples, rather than estimated from their bulk chemistry which is influenced by magma production (partial melting) and magmatic differentiation (crystallization and mineral accumulation) processes. Thus, the $\left(\frac{147 \mathrm{Sm}}{144 \mathrm{Nd}}\right)^{S}$ of the shergottite source used in Equation 2 is calculated from Equation 1. However, because calculation of the $\left(\frac{147 \mathrm{Sm}}{{ }^{144} \mathrm{Nd}}\right)^{S}$ ratio requires the age of source formation to be known, Equations 1 and 2 must be solved iteratively until they converge. This age calculation is therefore considered to be a three-stage model age despite the fact that the third stage of ${ }^{142} \mathrm{Nd} /{ }^{144} \mathrm{Nd}$ growth in the shergottites is ignored because of their young crystallization ages (Figure 1).

The model ages derived from Equation 2 are dependent on the $\left(\left(^{142} \mathrm{Nd} d\right)^{B}\right.$ ratio used in the expression. If Mars is assumed to have a chondritic ${ }^{142} \mathrm{Nd} /{ }^{144} \mathrm{Nd}$ value of 1.141813 (equivalent $\varepsilon^{142} \mathrm{Nd}=-0.21$ relative to our terrestrial standard value; e.g., Boyet and Carlson, 2005), the measured $\mathrm{Sm}-\mathrm{Nd}$ isotopic compositions of the enriched shergottite subgroup do not permit 
Equations 1 and 2 to converge. The average age of the source region of depleted shergottite subgroup is $4531 \pm 7 \mathrm{Ma}$, whereas the intermediate shergottites yield source region model ages that are older than the Solar System $(4589 \pm 50 \mathrm{Ma})$. The variation in the three-stage model ages for the depleted and intermediate shergottites, combined with the lack of convergence demonstrated by the $\mathrm{Nd}$ isotopic systematics of the enriched shergottites, is inconsistent with the assumption that shergottites evolved from a planet with a present-day bulk ${ }^{142} \mathrm{Nd} /{ }^{144} \mathrm{Nd}$ ratio of chondritic meteorites in three stages of evolution. However, if the present-day ${ }^{142} \mathrm{Nd} /{ }^{144} \mathrm{Nd}$ of the bulk planet is assumed be the same as the terrestrial value measured in our laboratory (1.141837) then the equations converge for all three subgroups of shergottites and yield an average age of $4526 \pm 87 \mathrm{Ma}$.

\subsubsection{Whole rock ${ }^{146} \mathrm{Sm}^{142} \mathrm{Nd}$ isochron age}

Constraining the age of planetary differentiation using the whole rock isochron method is based on the predication that the source regions of the shergottites formed contemporaneously from a common reservoir and thus have the same initial isotopic compositions. The age of martian planetary differentiation was originally defined using the $\mathrm{Rb}-\mathrm{Sr}$ system to be approximately $4.5 \mathrm{Ga}$ (Shih et al., 1982) because the initial ${ }^{87} \mathrm{Sr} /{ }^{86} \mathrm{Sr}$ ratio for the model isochron was very close to the initial ${ }^{87} \mathrm{Sr} /{ }^{86} \mathrm{Sr}$ value estimated for the Solar System. Borg et al. (2003) noted that the enriched and depleted shergottites source regions had ${ }^{87} \mathrm{Rb} /{ }^{86} \mathrm{Sr},{ }^{147} \mathrm{Sm} /{ }^{144} \mathrm{Nd}$, and ${ }^{176} \mathrm{Lu} /{ }^{177} \mathrm{Hf}$ ratios that closely approximated values determined for lunar magma ocean cumulates by Snyder et al. (1992), and suggested the Sm-Nd whole rock isochron could be used to constrain the differentiation age of Mars. Subsequent investigations of major and trace element compositions of the shergottite source regions confirmed that they are a close match to compositions of martian magma ocean cumulates that formed by crystallization of a common reservoir of chondritic composition (Borg and Draper, 2003; Elkins-Tanton et al., 2003). Thus, the shergottite source regions have geochemical characteristics that are consistent with derivation from a common reservoir at the same time and are therefore potentially in isotopic equilibrium.

The second approach used to determine the age of formation of the shergottite sources is based on ${ }^{146} \mathrm{Sm}-{ }^{142} \mathrm{Nd}$ whole rock isochrons constructed using the shergottite source ${ }^{147} \mathrm{Sm} /{ }^{144} \mathrm{Nd}$ ratios, calculated with Equation 1, and the corresponding ${ }^{142} \mathrm{Nd} /{ }^{144} \mathrm{Nd}$ ratio measured in the bulk meteorite samples. This approach has been extensively used in the geochemical community (e.g., Nyquist et al. 1995; Rankenburg et al., 2006; Boyet and Carlson, 2007; Caro et al., 2008; Brandon et al., 2009). The age of shergottite source formation $\left(T_{1}\right)$ is expressed as:

$$
\left.T_{1}=4567-\left(\frac{1}{-\lambda^{146}}\right) \ln \left[\frac{m}{\left(\frac{146 S m}{{ }^{144} S m}\right)^{S S I}\left({ }^{144} S m\right.}\right)^{S t d}\right]
$$


The slope $m$, and hence age, defined by the ${ }^{147} \mathrm{Sm} /{ }^{144} \mathrm{Nd}-{ }^{142} \mathrm{Nd} /{ }^{144} \mathrm{Nd}$ isochron is dictated by the ${ }^{147} \mathrm{Sm} /{ }^{144} \mathrm{Nd}$ ratios of the shergottite source region calculated from Equation 1 and plotted on the $\mathrm{x}$-axis of Figure 2. Because Equation 1 requires the age of source formation to be known, Equations 1 and 3 must be solved iteratively. The ${ }^{147} \mathrm{Sm}$ isotope is used to represent $\mathrm{Sm}$ concentrations on the $\mathrm{x}$-axis of this plot instead of the traditional ${ }^{144} \mathrm{Sm}$ isotope because this ratio is calculated from the ${ }^{143} \mathrm{Nd} /{ }^{144} \mathrm{Nd}$ ratio (Eq. 1). As a consequence, the slope derived from the isochron presented in Figure 2 yields an initial ${ }^{146} \mathrm{Sm} /{ }^{147} \mathrm{Sm}$ ratio rather than a ${ }^{146} \mathrm{Sm} /{ }^{144} \mathrm{Sm}$ ratio. Therefore, Equation 3 is formulated to yield an age from a slope in the form ${ }^{146} \mathrm{Sm} /{ }^{147} \mathrm{Sm}$. Importantly, the ${ }^{147} \mathrm{Sm} /{ }^{144} \mathrm{Sm}$ ratios of individual samples were measured and found to match the ratio determined on terrestrial rock standards, as well as the AMES Sm isotope standard (Table 3). Therefore this formulization yields results that are identical to results based on the slope determined from a ${ }^{144} \mathrm{Sm} /{ }^{144} \mathrm{Nd}-{ }^{142} \mathrm{Nd} /{ }^{144} \mathrm{Nd}$ isochron plot.

Equation 3 is used to calculate ages from the slope of the ${ }^{147} \mathrm{Sm} /{ }^{144} \mathrm{Nd}-{ }^{142} \mathrm{Nd} /{ }^{144} \mathrm{Nd}$ isochron plot (Figure 2). Slopes are regressed through the data using IsoPlot 4.15. The model age of silicate differentiation determined from our data using this approach is $4504 \pm 8 \mathrm{Ma}$. A slightly more precise age is calculated if the $\mathrm{Sm}-\mathrm{Nd}$ isotopic data obtained by Debaille et al. (2007) are included in this calculation. In this case, an age of $4503 \pm 6 \mathrm{Ma}$ is determined (MSWD $=0.48)$. Other published data sets increase the scatter on Figure 2 and do not help to better constrain the age of shergottite source formation. This is our preferred age of silicate differentiation determined using this approach. Uncertainties in the age calculation do not incorporate uncertainties associated with the initial ${ }^{146} \mathrm{Sm} /{ }^{144} \mathrm{Sm}$ of the Solar System of 0.00828 \pm 43 (Marks et al., 2014a) or with the half-life of ${ }^{146} \mathrm{Sm}$ of $103 \pm 5 \mathrm{Ma}$ (Friedman et al., 1966; Meissner et al., 1987). It is calculated however, that the uncertainty associated with the initial ${ }^{146} \mathrm{Sm} /{ }^{144} \mathrm{Sm}$ ratio and ${ }^{146} \mathrm{Sm}$ half-life translate to uncertainties on the final age of 8 and $3 \mathrm{Ma}$, respectively.

It should be noted that the difference in age reported here and the age of $4535 \pm 7 \mathrm{Ma}$ reported by Debaille et al. (2007) does not reflect significant differences in the measured Sm-Nd isotopic data. Instead, the difference reflects the fact that Debaille et al. (2007) calculated an age from the average $\mathrm{Sm}-\mathrm{Nd}$ isotopic composition of three depleted shergottites assuming bulk Mars has a chondritic ${ }^{142} \mathrm{Nd} /{ }^{144} \mathrm{Nd}$ ratio. However, unlike the three-stage model ages determined for individual samples using Equation 2, the age defined by the isochron (Figure 2) is not dependent on the assumed ${ }^{142} \mathrm{Nd} /{ }^{144} \mathrm{Nd}$ ratio for bulk Mars. As discussed above, the underlying assumption associated with this age is that the shergottite mantle source regions formed contemporaneously from a common reservoir. The geochemical and isotopic systematics of the shergottites support this contention (e.g., Borg et al., 2003; Elkins-Tanton, 2003; Symes et al., 2008) so that this isochron likely represents the age at which the shergottite sources formed from a common reservoir. The initial ${ }^{142} \mathrm{Nd} /{ }^{144} \mathrm{Nd}$ defined by the isochron therefore represents the composition of this reservoir at the time of shergottite source formation at $4504 \mathrm{Ma}$. The initial ${ }^{142} \mathrm{Nd} /{ }^{144} \mathrm{Nd}$ 
ratio determined from the ${ }^{146} \mathrm{Sm}^{-}{ }^{142} \mathrm{Nd}$ isochron is $1.141615 \pm 8$. A reservoir with a ${ }^{142} \mathrm{Nd} /{ }^{144} \mathrm{Nd}$ ratio of 1.141615 at $4504 \mathrm{Ma}$ would have a present-day ${ }^{142} \mathrm{Nd} /{ }^{144} \mathrm{Nd}$ ratio $1.141830 \pm 8$ if it also had a present-day ${ }^{147} \mathrm{Sm} /{ }^{144} \mathrm{Nd}$ ratio of chondritic meteorites of 0.1967 . In other words, the initial ${ }^{142} \mathrm{Nd} /{ }^{144} \mathrm{Nd}$ ratio determined from this whole rock isochron falls on an evolution curve for a reservoir with present-day ${ }^{147} \mathrm{Sm} /{ }^{144} \mathrm{Nd}$ and ${ }^{142} \mathrm{Nd} /{ }^{144} \mathrm{Nd}$ ratios of 0.1967 and 1.141830 (Figure 1). This implies that bulk Mars has Sm-Nd isotopic systematics that are similar to those inferred for Earth, and different from those measured in chondritic meteorites.

\subsubsection{Whole rock ${ }^{142} \mathrm{Nd} I^{144} \mathrm{Nd}-^{143} \mathrm{Nd} I^{144} \mathrm{Nd}$ isochron age}

The third approach to constrain the age of formation of the shergottite source regions from the previously undifferentiated martian mantle uses the present-day ${ }^{142} \mathrm{Nd} /{ }^{144} \mathrm{Nd}$ and ${ }^{143} \mathrm{Nd} /{ }^{144} \mathrm{Nd}$ ratios of the shergottite sources and is presented in Figure 3. Because the shergottite magmas formed after ${ }^{146} \mathrm{Sm}$ was extinct, the ${ }^{142} \mathrm{Nd} /{ }^{144} \mathrm{Nd}$ ratios of the shergottite source regions today are the same as those measured for the shergottite whole rocks. In contrast, the ${ }^{143} \mathrm{Nd} /{ }^{144} \mathrm{Nd}$ ratio of the shergottite source today must be calculated from the initial ${ }^{143} \mathrm{Nd} /{ }^{144} \mathrm{Nd}$ ratio of the sample at the time of crystallization and the ${ }^{147} \mathrm{Sm} /{ }^{144} \mathrm{Nd}$ calculated for the source using Equation 1. This approach is based on the fact that the slope on a ${ }^{143} \mathrm{Nd} /{ }^{144} \mathrm{Nd}$ versus ${ }^{142} \mathrm{Nd} /{ }^{144} \mathrm{Nd}$ diagram (or $\varepsilon^{143} \mathrm{Nd}-\varepsilon^{142} \mathrm{Nd}$ plot) corresponds to a three-stage model age (Borg et al., 2003; Foley et al., 2005).

The slope of a line on a ${ }^{143} \mathrm{Nd} /{ }^{144} \mathrm{Nd}-{ }^{142} \mathrm{Nd} /{ }^{144} \mathrm{Nd}$ plot is related to the formation age of the shergottite source region $\left(\mathrm{T}_{1}\right)$ by the equation:

(Eq. 4a)

$$
m=\frac{\left(\frac{{ }^{146} S m}{{ }^{144} S m}\right)^{S S I}\left(\frac{{ }^{144} S m}{{ }^{147} S m}\right)^{S t d}\left[e^{\left(-\lambda^{146}\left(T_{0}-T_{1}\right)\right)}\right]}{\left(e^{\lambda^{147} T_{1}}-1\right)}
$$

where $\left(\frac{{ }^{146} \mathrm{Sm}}{{ }^{144} \mathrm{Sm}}\right)^{\text {SSI }}$ is the initial Solar System value of 0.00828 (Marks et al. 2014a), $\left(\frac{{ }^{144} \mathrm{Sm}}{{ }^{147} \mathrm{Sm}}\right)^{\text {Std }}$ is the Sm isotopic composition of the AMES standard of 0.202419 (Table 4), and $\mathrm{T}_{0}$ is the age of the Solar System of 4567 Ma. Rearranging and taking the natural logs allows this equation to be expressed in terms of age of shergottite source formation:

(Eq. 4b) 


$$
T_{1}=\left\{\left(-\lambda^{146} T_{0}\right)-\ln \left[\left(e^{\lambda^{147} T_{1}}-1\right) \frac{(m)}{\left(\frac{{ }^{146} S m}{{ }^{144} S m}\right)^{S S I}\left(\frac{{ }^{144} S m}{{ }^{147} S m}\right)^{S t d}}\right]\right\}\left(\frac{1}{-\lambda^{146}}\right)
$$

Note that $\mathrm{T}_{1}$ is on both sides of the equation so that it must be solved iteratively. Solving the equation only takes a single iteration, however. The cancelation of terms in this derivation results in an age equation that is independent of the ${ }^{142} \mathrm{Nd} /{ }^{144} \mathrm{Nd}$ isotopic composition of the bulk planet.

If the slope $m$ is determined through regression on an $\varepsilon^{143} \mathrm{Nd}-\varepsilon^{142} \mathrm{Nd}$ plot instead of a ${ }^{143} \mathrm{Nd} /{ }^{144} \mathrm{Nd}-{ }^{142} \mathrm{Nd} /{ }^{144} \mathrm{Nd}$ plot, the expression is easily modified to solve for $\mathrm{T}_{1}$ by simply multiplying the slope by the ratio of values used to convert isotopic ratio measurements to epsilon notation.

(Eq. 4c)

$$
T_{1}=\left\{\left(-\lambda^{146} T_{0}\right)-\ln \left[\left(e^{\left.\lambda^{147} T_{1}-1\right)} \frac{\frac{\left(\frac{{ }^{142} N d}{144}\right)^{\text {Calc }}}{\left(\frac{143}{144} N\right)^{C a l c}(m)}}{\left(\frac{146}{144}\right)^{S S I}\left(\frac{144}{147}\right)^{S t d}}\right]\right\}\left(\frac{1}{-\lambda^{146}}\right)\right.
$$

Thus, for Nd measurements completed in our laboratory this ratio is expressed as:

(Eq. 4 d)

$$
\frac{\left(\frac{142 N d}{144 N d}\right)^{\text {Calc }}}{\left(\frac{143 N d}{144 N d}\right)^{C a l c}}=\frac{1.141837}{0.512638}
$$

The slope determined from a line regressed through the combination of our data and the data of Debaille et al. (2007) in Figure 3 is $0.01641 \pm 62(\mathrm{MSWD}=0.57)$. This corresponds to an age of $4504 \pm 6 \mathrm{Ma}$. This age agrees with the age determined by the ${ }^{146} \mathrm{Sm}-{ }^{142} \mathrm{Nd}$ method and is our preferred age for the formation of the shergottite source regions.

\subsubsection{Relationship between age calculations}


Although calculation of ages using the three approaches outlined in Equations 2, 3, and $4 b-4 c$ has been derived separately, the results are not independent for all applications. The formation ages of the shergottite source regions derived from the isochrons on Figure 2 and 3 represent a case where the ages are not independent. This stems from the fact that the ${ }^{147} \mathrm{Sm} /{ }^{144} \mathrm{Nd}$ ratio used in the ${ }^{147} \mathrm{Sm} /{ }^{144} \mathrm{Nd}-{ }^{142} \mathrm{Nd} /{ }^{144} \mathrm{Nd}$ isochron calculation is derived from the measured ${ }^{143} \mathrm{Nd} /{ }^{144} \mathrm{Nd}$ ratio that represents the $\mathrm{x}$-axis on the ${ }^{143} \mathrm{Nd}-{ }^{142} \mathrm{Nd}$ isochron diagram. Furthermore, ages derived for individual samples using Equation 2 are only independent if the ${ }^{142} \mathrm{Nd} /{ }^{144} \mathrm{Nd}$ ratio used in the equation is defined by terrestrial or chondritic materials. On the other hand, ages calculated from Equation 2 will agree with those defined by the isochrons if the ${ }^{142} \mathrm{Nd} /{ }^{144} \mathrm{Nd}$ ratio used in the equations is assumed to be the same as the initial ${ }^{142} \mathrm{Nd} /{ }^{144} \mathrm{Nd}$ values defined by the isochrons. Thus, the average of the three-stage model ages determined on individual samples is $4504 \pm 42 \mathrm{Ma}$, assuming that Mars had a bulk planet ${ }^{142} \mathrm{Nd} /{ }^{144} \mathrm{Nd}$ ratio of 1.141830 (Table 2).

The most significant difference between the various age calculations of source region formation is associated with how sensitive each age is to the values of variables used in the equations. As noted earlier, the ages determined on the source regions of individual shergottites are extremely sensitive to the ${ }^{142} \mathrm{Nd} /{ }^{144} \mathrm{Nd}$ ratio assumed for the bulk planet, whereas the isochron ages are independent of this parameter. If the bulk planet is assumed to have a presentday ${ }^{142} \mathrm{Nd} /{ }^{144} \mathrm{Nd}$ ratio that differs by more than $\sim 3 \mathrm{ppm}$, the ages calculated for individual shergottites shift outside analytical uncertainty associated with the isotopic measurements. The strong dependence of three-stage model ages determined for individual shergottites on the assumed ${ }^{142} \mathrm{Nd} /{ }^{144} \mathrm{Nd}$ ratio of the bulk planet, combined with observations that suggest that the chondritic ratio may be a poor proxy for other planetary bodies (Borg et al., 2011, 2013, 2014; Marks et al., 2014b) illustrates the main weakness of using this approach to calculate differentiation ages. Ages calculated using Equation 2 are also sensitive to the ${ }^{147} \mathrm{Sm} /{ }^{144} \mathrm{Nd}$ value used to represent the shergottite source composition. For example, an uncertainty on the ${ }^{147} \mathrm{Sm} /{ }^{144} \mathrm{Nd}$ ratio of the shergottite source of $1 \%$, corresponds to an uncertainty in age of $\sim 10$ Ma. In contrast, the ages determined using the isochron methods are not dependent on the isotopic composition of the bulk planet and are less sensitive to uncertainty in the ${ }^{147} \mathrm{Sm} /{ }^{144} \mathrm{Nd}$ ratios than are ages calculated for individual meteorites. For example, a $1 \%$ uncertainty in the ${ }^{147} \mathrm{Sm} /{ }^{144} \mathrm{Nd}$ ratio of the shergottite source region corresponds to $\sim 1 \mathrm{Ma}$ uncertainty on the ${ }^{147} \mathrm{Sm} /{ }^{144} \mathrm{Nd}-{ }^{142} \mathrm{Nd} /{ }^{144} \mathrm{Nd}$ and ${ }^{143} \mathrm{Nd}-{ }^{142} \mathrm{Nd}$ isochron ages.

Finally it is important to note that both the ${ }^{147} \mathrm{Sm} /{ }^{144} \mathrm{Nd}-{ }^{142} \mathrm{Nd} /{ }^{144} \mathrm{Nd}$ and ${ }^{143} \mathrm{Nd}-{ }^{142} \mathrm{Nd}$ isochron methods are applicable to age determinations from mineral isochrons of any planetary sample demonstrating evidence for live ${ }^{146} \mathrm{Sm}$. However, unlike the case for whole rock isochrons, these age determinations are not calculated using the same measured parameters and so are independent of each other. This stems from the fact that the ${ }^{147} \mathrm{Sm} /{ }^{144} \mathrm{Nd}$ of the mineral fractions is measured, not calculated from their ${ }^{143} \mathrm{Nd} /{ }^{144} \mathrm{Nd}$ ratios as is done for the shergottite whole rock isochrons. The ${ }^{147} \mathrm{Sm} /{ }^{144} \mathrm{Nd}$ versus ${ }^{142} \mathrm{Nd} /{ }^{144} \mathrm{Nd}$ mineral isochron ages require the ${ }^{147} \mathrm{Sm} /{ }^{144} \mathrm{Nd}$ ratios to be determined, whereas ${ }^{143} \mathrm{Nd} /{ }^{144} \mathrm{Nd}$ versus ${ }^{142} \mathrm{Nd} /{ }^{144} \mathrm{Nd}$ isochron ages are defined without even measuring the ${ }^{147} \mathrm{Sm} /{ }^{144} \mathrm{Nd}$ ratios. This is demonstrated in Table 5 in which 
ages calculated from equation $4 \mathrm{~b}$ using only $\mathrm{Nd}$ isotopic measurements of mineral fractions are compared to ${ }^{147} \mathrm{Sm}-{ }^{143} \mathrm{Nd}$ and ${ }^{146} \mathrm{Sm}-{ }^{142} \mathrm{Nd}$ mineral isochron ages we have recently published for lunar samples and an Allende CAI Al3S4. Because the ages derived from equations 3 and $4 \mathrm{~b}$ depend on different measured parameters, the $\mathrm{Nd}-\mathrm{Nd}$ isochron approach can potentially be applied to materials with recently disturbed $\mathrm{Sm} / \mathrm{Nd}$ ratios.

\subsection{6. ${ }^{142} \mathrm{Nd} /{ }^{144} \mathrm{Nd}$ ratio of bulk Mars}

Whereas limited fractionation of $\mathrm{Sm} / \mathrm{Nd}$ in geologic environments allows the ${ }^{147} \mathrm{Sm} /{ }^{144} \mathrm{Nd}$ ratios of bulk planets to be fairly well constrained by the analysis of chondritic meteorites, the bulk ${ }^{142} \mathrm{Nd} /{ }^{144} \mathrm{Nd}$ ratio appears to be more variable in planetary materials (e.g., Boyet et al., 2005; Andreasen and Sharma, 2006; Boyet and Carlson, 2010; Gannoun et al., 2011). The present-day ${ }^{142} \mathrm{Nd} /{ }^{144} \mathrm{Nd}$ ratio of bulk Mars can be estimated from the $\mathrm{Sm}-\mathrm{Nd}$ isochron diagram presented in Figure 2 assuming the isotopic systematics of the shergottites are representative of the bulk planet and that Mars has a ${ }^{147} \mathrm{Sm} /{ }^{144} \mathrm{Nd}$ value of 0.1967 (Figure 1). A present-day ${ }^{142} \mathrm{Nd} /{ }^{144} \mathrm{Nd}$ ratio of $1.141830 \pm 8\left(\varepsilon^{142} \mathrm{Nd}=-0.06 \pm 0.07\right)$ is derived from the initial ${ }^{142} \mathrm{Nd} /{ }^{144} \mathrm{Nd}$ defined by the $y$-intercept value of ${ }^{142} \mathrm{Nd} /{ }^{144} \mathrm{Nd}=1.1416154 \pm 75$ on the whole rock isochron in Figure 2. The $\varepsilon^{142} \mathrm{Nd}-\varepsilon^{143} \mathrm{Nd}$ isochron plot presented in Figure 3 also provides an estimate of the presentday ${ }^{142} \mathrm{Nd} /{ }^{144} \mathrm{Nd}$ ratio of Mars that is based on the assumption that bulk Mars has a present day ${ }^{143} \mathrm{Nd} /{ }^{144} \mathrm{Nd}$ ratio of chondritic meteorites of 0.512638 . In this case, the present-day ${ }^{142} \mathrm{Nd} /{ }^{144} \mathrm{Nd}$ ratio of bulk Mars is defined by the intercept of the whole rock isochron with ${ }^{143} \mathrm{Nd} /{ }^{144} \mathrm{Nd}=$ 0.512638 (Figure 3). The present-day ${ }^{142} \mathrm{Nd} /{ }^{144} \mathrm{Nd}$ of bulk Mars estimated from Figure 3 is $1.141830 \pm 2\left(\varepsilon^{142} \mathrm{Nd}=-0.06 \pm 0.02\right)$, and as expected, agrees with the value defined by the ${ }^{146} \mathrm{Sm}^{-}{ }^{142} \mathrm{Nd}$ isochron in Figure 2.

The initial ${ }^{142} \mathrm{Nd} /{ }^{144} \mathrm{Nd}$ ratio calculated for bulk Mars here is dependent, to some small degree, on the assumption that Mars has a chondritic ${ }^{147} \mathrm{Sm} /{ }^{144} \mathrm{Nd}$ ratio of 0.1967 . For example, if bulk Mars is assumed to have a present-day ${ }^{147} \mathrm{Sm} /{ }^{144} \mathrm{Nd}$ ratio of 0.206 , as proposed by Caro et al. (2008), the ${ }^{147} \mathrm{Sm} /{ }^{144} \mathrm{Nd}$ ratios calculated for the shergottite sources using equation 1 would change slightly. This would shift the initial ${ }^{142} \mathrm{Nd} /{ }^{144} \mathrm{Nd}$ ratio determined from the ${ }^{146} \mathrm{Sm}-{ }^{142} \mathrm{Nd}$ isochron in Figure 2 from $1.141615 \pm 8$ to $1.141607 \pm 8$. The age would also shift slightly from $4504 \mathrm{Ma}$ to $4501 \mathrm{Ma}$. Note, however, that the initial ${ }^{142} \mathrm{Nd} /{ }^{144} \mathrm{Nd}$ ratio of 1.141607 would still correspond to a present-day ${ }^{142} \mathrm{Nd} /{ }^{144} \mathrm{Nd}$ of $1.141830 \pm 8$ assuming growth between $4567 \mathrm{Ma}$ and $4501 \mathrm{Ma}$ occurred in a reservoir with a ${ }^{147} \mathrm{Sm} /{ }^{144} \mathrm{Nd}=0.206$. Thus, the initial ${ }^{142} \mathrm{Nd} /{ }^{144} \mathrm{Nd}$ ratio derived from the ${ }^{146} \mathrm{Sm} /{ }^{144} \mathrm{Nd}$ isochron is not significantly affected by the values of the ${ }^{147} \mathrm{Sm} /{ }^{144} \mathrm{Nd}$ ratio assumed for the bulk planet.

The ${ }^{142} \mathrm{Nd} /{ }^{144} \mathrm{Nd}$ of $1.141830 \pm 8$ calculated for bulk Mars today corresponds to a Solar System initial ${ }^{142} \mathrm{Nd} /{ }^{144} \mathrm{Nd}$ value of $1.141496 \pm 8$ at 4567 assuming a bulk ${ }^{147} \mathrm{Sm} /{ }^{144} \mathrm{Nd}$ ratio of 0.1967. This value is identical to the initial ${ }^{142} \mathrm{Nd} /{ }^{144} \mathrm{Nd}$ isotopic composition derived from the internal isochron of the Type B CAI Al3S4 from the Allende meteorite (Marks et al., 2014a). Furthermore, the present-day ${ }^{142} \mathrm{Nd} /{ }^{144} \mathrm{Nd}$ ratio estimated for bulk Mars from the isochron plots is 
within uncertainty of the value measured in our laboratory on terrestrial $\mathrm{Nd}$ standards (JNdi $=$ $1.141837 \pm 7$ ) and whole rock standards (BCR-2 $=1.141834 \pm 7$; Table 1$)$, suggesting that the $\mathrm{Sm}-\mathrm{Nd}$ isotopic systematics of martian, terrestrial, and the CAI parent reservoirs are very similar.

The initial $\mathrm{Nd}$ isotopic compositions determined here for Mars are based on the simplifying assumption that $\mathrm{Nd}$ evolution of the shergottites occurred in three stages. Thus, the $\mathrm{Sm}-\mathrm{Nd}$ isotopic systematics offer insights into the primordial isotopic composition of $\mathrm{Nd}$ inherited during accretion of the planet. Note however, that not all martian igneous samples are likely to have evolved in 3 stages of evolution. The fact that the Nakhlites fall off the isochrons defined by the shergottites (Debaille et al., 2009), therefore, likely reflects the fact that these samples had a more complex evolutionary history than the shergottites, and not necessarily that initial $\mathrm{Nd}$ isotopic composition estimated for Mars from the shergottites is inappropriate.

\subsection{Rubidium-strontium model age calculation}

The conclusion that Mars underwent planetary differentiation at $\sim 4.5 \mathrm{Ga}$ was originally proposed by Shih et al. (1982) on the basis of whole rock $\mathrm{Rb}-\mathrm{Sr}$ systematics of the shergottites. These authors noted that the bulk rock ${ }^{87} \mathrm{Rb} /{ }^{86} \mathrm{Sr}-{ }^{87} \mathrm{Sr} /{ }^{86} \mathrm{Sr}$ compositions of the Shergotty, Zagami, and ALH77005 fell near a $4.5 \mathrm{Ga}$ reference line that passed through the initial $\mathrm{Sr}$ isotopic composition of the Solar System derived from basaltic achondrites (Basaltic Achondrite Best Initial, BABI) by Papanastassiou and Wasserburg (1969). Shih et al. (1982) argued that the fact that the $\mathrm{Rb}-\mathrm{Sr}$ systematics scattered around a $\sim 4.5 \mathrm{Ga}$ model isochron reflected the fact that the bulk rock ${ }^{87} \mathrm{Rb} /{ }^{86} \mathrm{Sr}$ ratios are a rough approximation of the ratios of the shergottite source regions.

Figure 4 is a plot of bulk rock $\mathrm{Rb}-\mathrm{Sr}$ isotopic compositions of the shergottites for which we measured Sm-Nd isotopic compositions. The $\mathrm{Rb}-\mathrm{Sr}$ data demonstrate significant scatter about a 4.5 Ga BABI reference line. The basaltic lithologies from non-desert environments fall closest to the reference line, whereas meteorites from desert environments generally fall to the left of this line. This likely reflects the fact that many of the meteorites found in desert environments have undergone terrestrial weathering that has resulted in the addition of Sr. The presence of calcite in some of these samples (e.g., DaG 476) further supports this hypothesis (Zipfel et al., 2000). Note that not all meteorites found in desert environments lie to the left of the $4.5 \mathrm{Ga}$ reference line, indicating that weathering has been relatively mild in some samples such as Dhofar 019, NWA 4468, and NWA 856. Likewise, not all non-desert meteorites line on the $4.5 \mathrm{Ga}$ reference line. Deviation of these samples from the $4.5 \mathrm{Ga}$ reference line indicates that the bulk rock ${ }^{87} \mathrm{Rb} /{ }^{86} \mathrm{Sr}$ ratio is not a perfectly faithful representation of the ${ }^{87} \mathrm{Rb} /{ }^{86} \mathrm{Sr}$ ratio of the shergottite source regions of the meteorites. Slight accumulation of plagioclase, for example, will drive the ratio to the left in Figure 4 and accumulation of small amounts of trapped liquid enriched in $\mathrm{Rb}$ will drive the whole rocks to the right. Despite these disturbances, the $\mathrm{Rb}-\mathrm{Sr}$ 
isotopic systematics of the shergottites support the original hypothesis put forth by Shih et al. (1982) that the shergottite source regions formed at $4.5 \mathrm{Ga}$ and is consistent with the more precise age obtained from the $\mathrm{Sm}-\mathrm{Nd}$ isotopic system.

\section{DISCUSSION}

\subsection{Age of silicate differentiation}

The age of $4504 \pm 6 \mathrm{Ma}$ calculated for the formation of the shergottite source regions is in good agreement with most of the previous age determinations for martian silicate differentiation. These include $4525 \pm 18 \mathrm{Ma}$ (Borg et al., 1997), $4513^{+27} /{ }_{-33} \mathrm{Ma}$ (Borg et al. 2003), $4525^{+19} /_{-21}$ (Foley et al., 2005), and $4527 \pm 18 \mathrm{Ma}$ (Caro et al., 2008). Although the $\mathrm{Sm}-\mathrm{Nd}$ isotopic data obtained in this study and by Debaille et al. (2007) are in excellent agreement, the ages calculated from the data differ outside analytical uncertainty. This reflects the fact that the age of $4535 \pm 7$ Ma calculated by Debaille et al. (2007) for three depleted shergottite source regions is a three-stage model age that assumes Mars had a chondritic ${ }^{142} \mathrm{Nd} /{ }^{144} \mathrm{Nd}$ isotopic composition (Eq. 2). As noted above, model ages calculated for individual samples assuming a chondritic ${ }^{142} \mathrm{Nd} /{ }^{144} \mathrm{Nd}$ isotopic composition fail to converge for all shergottites, suggesting that either the model calculation uses an incorrect parameter, or that the enriched and intermediate shergottites have had a more complex evolutionary history than the depleted shergottites.

Debaille et al. (2007) do in fact suggest that the sources of the enriched and intermediate shergottites contain a contribution from a younger reservoir that is absent from the depleted shergottite source. The existence of the younger enriched reservoir is based on the observation that the ${ }^{147} \mathrm{Sm} /{ }^{144} \mathrm{Nd}$ ratios of the shergottite bulk rocks are higher than the ${ }^{147} \mathrm{Sm} /{ }^{144} \mathrm{Nd}$ ratios calculated for their sources using measured ${ }^{143} \mathrm{Nd} /{ }^{144} \mathrm{Nd}$ ratios. This relationship between the ${ }^{147} \mathrm{Sm} /{ }^{144} \mathrm{Nd}$ ratios of the shergottite bulk rocks and the ${ }^{147} \mathrm{Sm} /{ }^{144} \mathrm{Nd}$ ratios calculated for their sources is inconsistent with partial melting of olivine-pyroxene cumulates assumed to be representative of the mantle sources from which these meteorites are derived. Debaille et al (2007) calculated the model age of the enriched shergottite source to be $4457 \mathrm{Ma}$ from the ${ }^{147} \mathrm{Sm} /{ }^{144} \mathrm{Nd}$ and ${ }^{142} \mathrm{Nd} /{ }^{144} \mathrm{Nd}$ ratios inferred for this reservoir. They defined the ${ }^{147} \mathrm{Sm} /{ }^{144} \mathrm{Nd}$ ratio of this enriched reservoir to be $\leq 0.159$ from the intersection of a line regressed through the ${ }^{147} \mathrm{Sm} /{ }^{144} \mathrm{Nd}$ ratios measured for the bulk rocks versus ${ }^{147} \mathrm{Sm} /{ }^{144} \mathrm{Nd}$ ratios calculated for the meteorite sources and a 1:1 line on Figure 5. Debaille et al (2007) defined the present-day ${ }^{142} \mathrm{Nd} /{ }^{144} \mathrm{Nd}$ of the reservoir by the intersection of a line regressed through a plot of the shergottite $\mathrm{Nd}-\mathrm{Nd}$ isotopic data and a $\mathrm{Nd}$ isotope growth curve modeled from a chondritic starting composition for a reservoir with a ${ }^{147} \mathrm{Sm} /{ }^{144} \mathrm{Nd}$ ratio of $\leq 0.159$. The age for the reservoir was estimated from its ${ }^{147} \mathrm{Sm} /{ }^{144} \mathrm{Nd}$ and present-day ${ }^{142} \mathrm{Nd} /{ }^{144} \mathrm{Nd}$ ratios assuming bulk Mars had a chondritic $\mathrm{Nd}$ bulk isotopic composition. 
Figure 5 is a reproduction of the ${ }^{147} \mathrm{Sm} /{ }^{144} \mathrm{Nd}$ shergottite whole rock versus ${ }^{147} \mathrm{Sm} /{ }^{144} \mathrm{Nd}$ shergottite source region plot that uses all currently available data. Whereas the older data were essentially linear, several newer data points for Tissint (Brennecka et al., 2014), Dhofar 019 (Caro et al., 2008; this study) and NWA 480 (this study) lie to the left of the line used to define the ${ }^{147} \mathrm{Sm} /{ }^{144} \mathrm{Nd}$ ratio of the enriched reservoir by Debaille et al. (2007). The fact that shergottites derived from source regions with similar ${ }^{147} \mathrm{Sm} /{ }^{144} \mathrm{Nd}$ ratios have different bulk rock

${ }^{147} \mathrm{Sm} /{ }^{144} \mathrm{Nd}$ ratios suggests the ${ }^{147} \mathrm{Sm} /{ }^{144} \mathrm{Nd}$ of the bulk rocks does not reflect binary mixing between enriched and depleted reservoirs and therefore probably should not be used to constrain the ${ }^{147} \mathrm{Sm} /{ }^{144} \mathrm{Nd}$ ratio of the enriched reservoir. Consequently the significance of the $4457 \mathrm{Ma}$ age derived for a reservoir with ${ }^{147} \mathrm{Sm} /{ }^{144} \mathrm{Nd}$ of 0.159 is not clear.

\subsection{Differentiation of Mars}

Any petrogenetic model for martian differentiation must account for three observations: (1) ${ }^{182} \mathrm{~W}$ isotopic compositions of the shergottites and nakhlites range from $\sim+0.65$ to +3 epsilon units, respectively, (2) silicate differentiation of the shergottite source region occured at $4504 \pm 6$ $\mathrm{Ma}$, and (3) the fact that the nakhlites fall to the left of the $4567 \mathrm{Ma} \mathrm{Nd-Nd}$ isochron on Figure 3. If the $\mathrm{Hf}-\mathrm{W}$ and $\mathrm{Sm}-\mathrm{Nd}$ isotopic data are interpreted to record silicate differentiation at 4504 $\mathrm{Ma}$ alone, then the $\mathrm{Hf} / \mathrm{W}$ ratios of the shergottite and nakhlite source regions must range from approximately 50 to 300. Partition coefficients for $\mathrm{W}$ and Hf determined by Shearer and Righter (2003) suggest that $\mathrm{Hf}$ is 3 to 7 times more compatible in clinopyroxene and 30 to 70 times more compatible in garnet. Nevertheless, these authors demonstrate that it is unlikely that even a garnet and clinopyroxene bearing mantle will have high enough $\mathrm{Hf} / \mathrm{W}$ ratio to yield $\mathrm{W}$ isotopic composition radiogenic enough to serve as the nakhlite source region if it formed at $4504 \mathrm{Ma}$. Another problem with the hypothesis that $\mathrm{W}$ isotopic differences between the nakhlites and shergottites reflect silicate differentiation at $4504 \mathrm{Ma}$ is the observation that the ${ }^{142} \mathrm{Nd}$ isotopic composition of the nakhlites falls to the right of the $4567 \mathrm{Ma} \mathrm{Nd-Nd}$ isochron on Figure 3 indicating that the nakhlite $\mathrm{Nd}$ isotopic compositions did not evolve in only 3 stages. Although a unique differentiation history for the nakhlites probably cannot be derived from their $\mathrm{Nd}$ isotopic systematics, late incompatible-element enrichment of the nakhlite source occurring between $4504 \mathrm{Ma}$ and the $\sim 1.3 \mathrm{Ga}$ crystallization age of the nakhlites is perhaps the simplest explanation for their $\mathrm{Nd}$ isotopic systematics. In any case, the variation in $\mathrm{W}$ and $\mathrm{Nd}$ isotopic compositions of the shergottites and nakhlites cannot result from differences in source mineralogy produced by silicate differentiation occurring at $4504 \mathrm{Ma}$ alone.

Alternatively, the ${ }^{182} \mathrm{~W}$ and ${ }^{142} \mathrm{Nd}$ isotopic compositions of the shergottites and nakhlites might reflect a combination of fractionation events associated with core formation and silicate differentiation. A relatively simple scenario associated with this hypothesis is that the ${ }^{182} \mathrm{~W}$ of the shergottites reflects an early core formation event that imparted a $\sim 0.65 \varepsilon^{182} \mathrm{~W}$ anomaly on the entire silicate mantle. In this case the best estimate of the age of core formation may be the 
average shergottite Hf-W age of $4559 \pm 8 \mathrm{Ma}$. If this is correct, then there must be an extended period of $55 \pm 13 \mathrm{Ma}$ between core formation at $4559 \mathrm{Ma}$ and silicate differentiation at $4504 \mathrm{Ma}$ (Figure 6, Option 1). A nakhlite source region forming from a homogeneous mantle with the same $\mathrm{W}$ isotopic composition as inherited by the shergottite source regions must have an Hf/W ratio of $\sim 200$ if the source region formed at $4504 \mathrm{Ma}$. This ratio is higher than those predicted for mantle cumulates based on partition studies of Hf and W (Shearer and Righter, 2003). Thus, in order to account for the difference in $\mathrm{W}$ isotopic compositions between the shergottites and nakhlites, the nakhlite source must form substantially before the shergottite source regions, requiring the martian magma ocean to cool slowly. Although some thermal modeling initially suggested that a shallow terrestrial magma ocean would cool in $100 \mathrm{Ma}$ to $200 \mathrm{Ma}$ in the presence of a thick atmosphere (e.g. Abe, 1997), more recent thermal modeling, incorporating additional constraints such as complete compositional information, mineralogy, and internal dynamics of the Mars (Elkins-Tanton; 2008; Labrun et al. 2013) demonstrates that mantle solidification likely occurred in less than $5 \mathrm{Ma}$ even in the presence of a thick atmosphere. Thus, the discrepancy between the $\mathrm{Hf}-\mathrm{W}$ and $\mathrm{Sm}-\mathrm{Nd}$ model ages is difficult to attribute to slow cooling of a magma ocean without an additional source of heat.

Another possibility is that $\mathrm{Hf} / \mathrm{W}$ ratios of the martian mantle were highly variable reflecting either heterogeneous core formation or late addition of material with variable ${ }^{182} \mathrm{~W}$ isotopic compositions. In this case, it is difficult to place firm constraints on the timing of core formation from the Hf-W isotopic system (Kleine and Halliday, 2006). Likewise, the $4504 \mathrm{Ma}$ $\mathrm{Nd}$ model age of shergottite source formation almost certainly would not constrain the timing of a planet-wide differentiation event. Instead, the $4504 \mathrm{Ma}$ age would likely record the age at which a portion of the mantle differentiated in isolation from other mantle regions. This scenario of martian differentiation (Figure 6, Option 2) is consistent with protracted accretion of a heterogeneous body that occurs contemporaneously with localized melting and differentiation. If accretion occurred over an extended interval, then solidification of portions of Mars could be delayed despite rapid heat flow from the planet as implied by thermal modeling (Figure 5; Option 2). Late accretion is expected to add heat into the system locally and could, in principle, help to maintain molten, undifferentiated, domains on the planet. If this scenario is correct, then accretion must have lasted $\sim 60 \mathrm{Ma}$ in order to postpone differentiation of the shergottite mantle source regions until $4504 \mathrm{Ma}$. In this case, the metal/silicate segregation event recorded by the ${ }^{182} \mathrm{Hf}-{ }^{182} \mathrm{~W}$ isotopic system may reflect Hf/W fractionation that occurred on planetesimals prior to accretion, during martian core formation, and during martian silicate differentiation. This scenario is appealing not only because it satisfies the thermal modeling, but also because it accounts for elevated abundances of highly siderophile elements (HSE) observed in the martian mantle. High abundances of these elements in terrestrial mantles are inconsistent with formation of metallic cores in closed geochemical systems because HSEs are strongly partitioned into the metal phase (e.g., Brandon et al., 2012). Accretion that occurred after core formation terminated could replenish the martian mantle in HSEs. Heterogeneous distribution of the later accreting material in the martian mantle might also contribute to the observed isotopic variation of ${ }^{182} \mathrm{~W}$ in the different classes of martian meteorites. 
A variation of this accretion scenario, in which protracted accretion of a heterogeneous body that occurs contemporaneously with localized melting and differentiation, involves a late giant impact on Mars (Figure 6, Option 3). Such an impact has been suggested to be responsible for the formation of the northern lowlands of Mars (Wilheims and Squires, 1984; AndrewsHanna et al., 2008; Marinova et al., 2008; Nimmo et al., 2008). Geophysical modeling of a martian giant impact event suggests that: (1) both Mars and the impactor are likely to be differentiated at the time of impact (Yoshino et al., 2003; Neumann et al., 2012), (2) the impact could heat a significant portion of the planet and induce melting (Tonks and Melosh, 1993; Monteux et al., 2007; Arkani-Hamed and Ghods, 2011), and (3) chemical global equilibrium between Mars and the impactor was probably not attained after the impact (Monteux and ArkaniHamed, 2013). The $\mathrm{Sm}-\mathrm{Nd}$ age could therefore record a differentiation event associated with cooling of a large, but not globally extensive, portion of the mantle after the impact. This hypothesis is consistent with the fact that the shergottites fall into a few young crystallization age groups (Nyquist et al., 2001; Borg and Drake, 2005) and many have identical cosmic ray exposure ages (Nishiizumi et al., 2011) suggesting that they probably do not represent an extensive sampling of the martian surface (Nyquist et al., 2001; Borg and Drake, 2005; Brennecka et al., 2014). If this hypothesis is correct, then the age recorded in the $\mathrm{Sm}-\mathrm{Nd}$ systematics of the shergottites might reflect a local, rather than a global, differentiation event. The Sm-Nd age would not define the age of martian silicate differentiation, but instead would place temporal constraints on the timing of a martian giant impact. Differences in ${ }^{182} \mathrm{~W}$ isotopic compositions observed in martian meteorites could reflect a combination of the heterogeneous distribution of $\mathrm{W}$ derived from Mars and the impactor in the martian mantle, as well as a variable extents and ages of Hf/W fractionation associated with silicate differentiation. This hypothesis implies that planet formation is a stochastic process in which accretion and differentiation occur contemporaneously over tens of millions of years, to produce numerous compositionally distinct geochemical reservoirs. If this scenario is correct, then neither ${ }^{142} \mathrm{Nd}$ nor ${ }^{182} \mathrm{~W}$ constrain the timing of planetary scale differentiation events. The Sm-Nd age of $4504 \pm 6 \mathrm{Ma}$ therefore only provides a minimum estimate for the time when accretion terminated.

\section{CONCLUSIONS}

A mathematical expression to calculate an age from the slope defined by the regression on the ${ }^{142} \mathrm{Nd} /{ }^{144} \mathrm{Nd}-{ }^{143} \mathrm{Nd} /{ }^{144} \mathrm{Nd}$ isochron is presented. It is used to estimate an age of $4504 \pm 6$ Ma for the formation of the shergottite source regions using Sm-Nd isotopic data obtained on 11 shergottite samples. The ${ }^{142} \mathrm{Nd} /{ }^{144} \mathrm{Nd}-{ }^{143} \mathrm{Nd} /{ }^{144} \mathrm{Nd}$ isochron age is concordant with the ${ }^{146} \mathrm{Sm}-{ }^{142} \mathrm{Nd}$ whole rock isochron age. Both isochron ages are concordant with model ages calculated for individual samples, provided bulk Mars is assumed to have a near-terrestrial ${ }^{142} \mathrm{Nd} /{ }^{144} \mathrm{Nd}$ value of $1.141830\left(\varepsilon^{142} \mathrm{Nd}=-0.06\right)$. The $\mathrm{Nd}-\mathrm{Nd}$ method is the preferred method to establish the age of the shergottite mantle source regions because it is not dependent on the 
assumed ${ }^{142} \mathrm{Nd} /{ }^{144} \mathrm{Nd}$ ratio of bulk Mars nor strongly influenced by uncertainties associated with estimates of ${ }^{147} \mathrm{Sm} /{ }^{144} \mathrm{Nd}$ ratios of the shergottite source regions. The $4504 \mathrm{Ma}$ age for the formation of the shergottite source regions requires that either solidification of the primordial martian magma ocean occurred late in the accretion history of the Solar System or that the Hf-W and $\mathrm{Sm}-\mathrm{Nd}$ fractionation recorded in the meteorites does not reflect a global differentiation process. Prolonged cooling of the magma ocean is not consistent with thermal modeling that suggests that this process requires only a few million years to complete. If the thermal modeling is correct, then an additional heat source appears to be required to keep the martian interior hot until $4504 \mathrm{Ma}$. Protracted accretion occurring more or less continuously for $\sim 60 \mathrm{Ma}$ or a giant impact occurring just prior to 4504 Ma might provide such heat and could account for some of the isotopic compositions of the shergottite suite. Such an impact could also produce a mantle that is compositionally heterogeneous on a planetary scale. In this case, the $4504 \pm 6 \mathrm{Ma}$ $\mathrm{Sm}-\mathrm{Nd}$ model age recorded in the shergottites would reflect differentiation associated the cooling of the mantle following a giant impact.

\section{Acknowledgments}

This work was performed under the auspices of the US Department of Energy by Lawrence Livermore National Laboratory under Contract DE-AC52-07NA27344. This document has been assigned release number LLNL-JRNL-656776. The work was supported by National Aeronautics and Space Administration NASA Cosmochemistry grant NNH12AT84I (P.I. Borg). The authors are grateful for reviews of this manuscript by Q. Yin, V. Debaille, R. Andreasen, and M. Norman, as well as discussions with A. Gaffney and B. Jacobsen.

\section{References:}

Abe Y. (1997) Thermal and chemical evolution of the terrestrial magma ocean. Phys. Earth Planet. Inter. 100, 27-39.

Amelin Y., Kaltenbach A., Iizuka T., Striling C. H., Ireland T. R., Petaev M., and Jacobsen S. B (2010) U-Pb chronology of the Solar System's oldest solids with variable ${ }^{238} \mathrm{U} /{ }^{235} \mathrm{U}$. Earth Planet. Sci. Lett. 300, 343-350.

Andreasen R. and Sharma M. (2006) Solar nebula heterogeneity in p-process samarium and neodymium isotopes. Science 314, 806-809.

Andrews-Hanna J. C., Zuber M. T., and Banerdt W. B. (2008) The Borealis basin and the origin of the martian crustal dichotomy. Nature 453, 1212-1215.

Arkani-Hamed J. and Ghods A. (2011) Could giant impact cripple core dynamos of small terrestrial planets? Icarus 212, 920-934. 
Blichert-Toft J., Gleason J. D., Télouk P., and Alberède F. (1999) The Lu-Hf geochemistry of shergottites and the evolution of the martian mantle-crust system. Earth Planet. Sci. Lett. 173, 25-29.

Borg L. E. and Draper D. A. (2003) A petrogenetic model for the origin and compositional variation of the martian basaltic meteorites. Meteor. Planet. Sci. 38, 1713-1731.

Borg L. E. and Drake M. J. (2005) A Review of Meteorite Evidence for the Timing of Magmatism and of Surface or Near-Surface Liquid Water on Mars. J. Geophys. Res. 110, E12SO3, doi:10.1029/2005JE002402.

Borg L. E., Nyquist L. E., Wiesmann, H., Shih, C.-Y. (1997) Constraints on martian differentiation processes from $\mathrm{Rb}-\mathrm{Sr}$ and $\mathrm{Sm}-\mathrm{Nd}$ isotopic analyses of the basaltic shergottite QUE 94201. Geochim. Cosmochim. Acta 61, 4915-4931.

Borg L. E., Nyquist L. E., Reese Y., Wiesmann H., Shih C.-Y., Ivanova M., Nazarov M. A., and Taylor, L.A. (2001) The age of Dhofar 019 and its relationship to the other Martian meteorites Lunar Planet. Sci. XXXIII Abstr. \#1144, CD-ROM.

Borg L. E., Nyquist L. E., Wiesmann H., and Reese Y. (2002) Constraints on the petrogenesis of martian meteorites from $\mathrm{Rb}-\mathrm{Sr}$ and $\mathrm{Sm}-\mathrm{Nd}$ isotopic systematics of the lherzolitic shergottites ALH77005 and LEW88516. Geochim. Cosmochim. Acta 66, 2037-2053.

Borg L. E., Nyquist L. E., Wiesmann H., Reese Y. (2003) The age of Dar al Gani 476 and the differentiation history of the martian meteorites inferred from their Rb-Sr, Sm-Nd, and LuHf isotopic systematics. Geochim. Cosmochim. Acta 67, 3519-3536.

Borg L. E., Edmunson J., Asmerom Y. (2005) Constraints on the U-Pb Isotopic Systematics of Mars Inferred from a Combined U-Pb, $\mathrm{Rb}-\mathrm{Sr}$, and $\mathrm{Sm}-\mathrm{Nd}$ Isotopic Study of the Martian Meteorite Zagami. Geochim. Cosmochim. Acta. 69, 5819-5830.

Borg L. E., Connelly J. N., Boyet M., Carlson R. W. (2011) Evidence that the Moon is either young or did not have a global magma ocean. Nature 477, 70-72.

Borg L. E., Connelly J. N. Cassata W. Gaffney A. M. Carlson R. W. Papanastassiou D. A., Ramon E., Lindvall R., Bizarro M. (2013) Evidence for Widespread Magmatic Activity at $4.36 \mathrm{Ga}$ in the Lunar Highlands from Young Ages Determined on Troctolite 76535. Lunar Planet. Sci. XLIV Abstr. \#1563.

Borg L. E., Brennecka G. A., Marks N., and Symes S. J. K. (2014) Neodymium Isotopic Evolution of the Solar System Inferred from Isochron Studies of Planetary Materials. Lunar Planet. Sci. XLIV Abstr. \#1037

Boyet M. and Carlson R.W. ( 2005) ${ }^{142} \mathrm{Nd}$ evidence for early (>4.53) global differentiation of the silicate Earth. Science 309, 576-581.

Boyet M. and Carlson, R. W. (2007) A highly depleted moon or a non-magma ocean origin for the lunar crust? Earth Planet. Sci. Lett. 263, 505-516. 
Boyet M., Carlson R. W., and Horan M. (2010) Old Sm-Nd ages for cumulate eucrites and redetermination of the solar system initial ${ }^{146} \mathrm{Sm} /{ }^{144} \mathrm{Sm}$ ratio. Earth Planet. Sci. Lett. 291, 172-181.

Brandon A. D., Lapen T. L., Debaille V., Beard B. L., Rankenburg K., and Neal C. R. (2009) Re-evaluating ${ }^{142} \mathrm{Nd} /{ }^{144} \mathrm{Nd}$ in lunar mare basalts with implications for the early evolution and bulk Sm/Nd of the Moon. Geochim. Cosmochim.Acta 73, 6421-6445.

Brandon A. D., Puchtel I. S., Walker R. J., Day J. M. D. Irving, A. J. Taylor, L. A. (2012) Evolution of the martian mantle inferred from the ${ }^{187} \mathrm{Re}_{-}{ }^{187} \mathrm{Os}$ isotope and highly siderophile element abundance systematics of shergottite meteorites. Geochim. Cosmochim. Acta. 76, 206-235.

Brennecka G. A., Borg L. E., and Wadhwa M. (2014) Insights into the Martian Mantle: The Age and Isotopics of the Meteorite Fall Tissint. Meteor. Planet. Sci. 49, 412-418.

Carlson R. W., Borg L. E., Gaffney A. M., and Boyet M. (2014) Rb-Sr, Sm-Nd and Lu-Hf Isotope Systematics of the Lunar Mg-Suite: The Age of the Lunar Crust and its Relation to the Time of Moon Formation. Proc. Roy. Soc. London.

Caro G., Bourdon B., Halliday A. N., and Quitte, G. (2008) Super-chondritic Sm/Nd ratios in Mars, the Earth and the Moon. Nature 452, 336-339.

Chambers J. E. (2004) Planetary accretion in the inner solar system. Earth Planet. Sci. Lett. 233, 241-252

Connelly J. N., Bizzarro M., Krot A. N., Nordlund A., Wielandt D., and Ivanova M. A. (2012). The Absolute Chronology and Thermal Processing of Solids in the Solar Protoplanetary Disk. Science 338, 651-655.

Dauphas N. and Pourmand A. (2011) Hf-W-Th evidence for rapid growth of Mars and its status as a planetary embryo. Nature $473,489-492$.

Debaille V., Yin Q. -Z., Brandon A. D., and Jacobsen, B. (2008) Martian mantle mineralogy investigate by the ${ }^{176} \mathrm{Lu}^{-176} \mathrm{Hf}$ and ${ }^{147} \mathrm{Sm}^{-}{ }^{143} \mathrm{Nd}$ systematics of shergottites. Earth Planet. Sci. Lett. 269, 186-199.

Debaille V., Brandon A. D., and Yin Q. -Z., Jacobsen, B. (2007) Coupled ${ }^{142} \mathrm{Nd}^{-143} \mathrm{Nd}$ evidence for a protracted magma ocean in Mars. Nature 450, 525-528.

Elkins-Tanton L. T. (2008) Linked magma ocean solidification and atmospheric growth for Earth and Mars. Earth. Planet. Sci. Lett. 271, 181-191.

Elkins-Tanton L. T., Parmentier E. M., and Hess P. C. (2003) Magma ocean fractional crystallization and cumulate overturn in terrestrial planets: implications for Mars. Meteor. Planet. Sci., 38, 1753-1771.

Foley C. N., Wadhwa M., Borg L. E., Janney P. E., Hines R., and Grove T. L. (2005) The early differentiation history of Mars from ${ }^{182} \mathrm{~W}-{ }^{142} \mathrm{Nd}$ isotope systematics in the SNC meteorites. Geochim. Cosmochim. Acta 69, 4557-4571. 
Friedman A. M., Milsted J., Metta D., Henderson D., Lerner J., Harkness A. L., and D. J. Rok Op (1966) Alpha Decay Half Lives of ${ }^{148} \mathrm{Gd}{ }^{150} \mathrm{Gd}$ and ${ }^{146} \mathrm{Sm}$. Radiochima Acta 5, 192-194.

Gannoun A., Boyet M., Rizo H., El Goresy A. ${ }^{146} \mathrm{Sm}^{-142} \mathrm{Nd}$ systematics measured in enstatite chondrites reveals a heterogeneous distribution of ${ }^{142} \mathrm{Nd}$ in the solar nebula. Proc. Nat. Acad. Sci. 108, 7693-7697.

Halliday A. N., and Kleine,T. (2006) Meteorites and the timing, mechanisms, and conditions of terrestrial planet accretion and early differentiation. In Meteorites and the early solar system II (eds. D. S. Lauretta and H. Y. McSween Jr.) University of Arizona Press, pp. 775-801.

Harper C. L., Nyquist L. E., Bansal B., Wiesmann H., and Shih, C. -Y. (1995) Rapid accretion and early differentiation of Mars indicated by ${ }^{142} \mathrm{Nd} /{ }^{144} \mathrm{Nd}$ in SNC meteorites. Science 267, 213-217.

Herd C. D. K., Borg L. E., Jones J. H., Papike J. J. (2002) Oxygen fugacity and geochemical variations in the martian basalts: Implications for martian basalt petrogenesis and the oxidation state of the upper mantle of Mars. Geochim. Cosmochim. Acta 66, 2025-2036.

Jacobsen S. B. and Wasserburg G. J. (1980) Sm-Nd isotopic evolution of chondrites. Earth Planet. Sci. Lett. 50, 139-156.

Jones J. H. (1989) Isotopic relationships among the shergottites, the nakhlites, and chassigny. Proc. $19^{\text {th }}$ Lunar Planet. Sci. Conf. pp. 465-474.

Kleine T., Touboul M., Bourdon B., Nimmo F., Mezger K., Palme H., Jaconsen S. B., Yin Q. Z., Halliday A. N. (2009) Hf-W chronology of the accretion and early evolution of asteroids and terrestrial planets. Geochim. et Cosmochim. Acta 73, 5150-5188.

Kleine T., Mezger,K., Munker C., Palmer H., and Bischoff A. (2004) ${ }^{182} \mathrm{Hf}-{ }^{182} \mathrm{~W}$ isotope systematics of chondrites, eucrites and martian meteorites: Chronology of core formation and early mantle differentiation in Vesta and Mars. Geochim. Cosmochim. Acta 68, 29352946.

Kinoshita N., Paul M., Kashiv Y., Collon P., Deibel C. M., DiGiovine B., Greene J. P., Henderson D. J, Jiang C. L., Marley S. T., Nakanishi T, Pardo R. C., Rehm K. E., Roberston D, Scott R, Schmitt C, Tang X. D., Vondrasek R., and Yokoyama A. (2012) A Shorter ${ }^{146} \mathrm{Sm}$ Half-Life Measured and Implications for ${ }^{146} \mathrm{Sm}-{ }^{142} \mathrm{Nd}$ Chronology in the Solar System. Science 335, 1614-1617.

Lebrun, T., H. Massol, E. Chassefière, A. Davaille, E. Marcq, P. Sarda, F. Leblanc, and G. Brandeis (2013), Thermal evolution of an early magma ocean in interaction with the atmosphere. $J$. Geophys. Res. Planets 118, 1155-1176, doi:10.1002/jgre.20068

Marks N. E., Borg L. E., Hutcheon I. D., Jacobsen B., Clayton R. N. (2014a) Samariumneodymium chronology of an Allende calcium-aluminum-rich inclusion with implications for ${ }^{146} \mathrm{Sm}$ isotopic evolution. Earth Planet. Sci. Lett.405, 15-24.

Marks et al. (2014b) Additional evidence for young ferroan anothositic magmatism on the Moon from Sm-Nd isotopic measurements of 60016 clast 3A. Lunar. Planet. Sci. XLV Abstract \#1129. 
Marks N. E., Borg L. E., Gaffney A. M. (2010) The Relationship of Northwest Africa 4468 to the Other Incompatible Element-enriched Shergottites Inferred from its $\mathrm{Rb}-\mathrm{Sr}$ and $\mathrm{Sm}-\mathrm{Nd}$ Isotopic Systematics. Lunar Planet.Sci. XLI Houston TX. abstract \#2064.

Marinova M. M., Aharonson O., and Asphaug E. (2008) Mega-impact formation of the Mars hemispheric dichotomy. Nature. 453, 1216-1219.

Meissner F., Schmidt-Ott W._D., and Ziegler L. (1987) Half-life and $\alpha$-ray energy of ${ }^{146} \mathrm{Sm}$. Z. Phys. A. - Atomic Nucl. 327, 171-174.

Mezger K., Debaille V., and Kleine T. (2013) Core formation and mantle differentiation on Mars. Space Sci. Rev. 174, 27-48.

Monteux J., Coltice N., Dubuffet F., and Ricard Y. (2007) Thermo-mechanical adjustment after impacts during planetary growth. Geophys. Res. Lett. 34, L24201.

Monteux J. and Arkani-Hamed J. (2013) Consequences of giant impacts in early Mars: Core merging and Martian dynamo. J. Geophys. Res. Planets. 119, doi 10.1002/2013JE004587.

Neumann W. Breuer D., and Spohn T. (2012) Differentiation and core formation in accreting planetismals. Astron. Astrophys. S43, A141, 23.

Nimmo F., Hart S. D., Korycansky D. G., and Agnor C. B. (2008) Implications of an impact origin for the Martian hemispheric dichotomy. Nature 453, 120-1223.

Nimmo F. and Kleine, T. (2007) How rapidly did Mars accrete? Uncertainties in the Hf-W timing or core formation. Icarus 191, 497-504.

Nishiizumi K., Nagao K., Caffee M. W., Jull A. J. T., and Irving A. J. (2011) Cosmic-ray exposure chronologies of depleted olivine-phyric shergottites. Lunar. Planet. Sci. XLII Abstract \#2371.

Nyquist L. E., Bogard D. D., Shih C. -Y., Greshake A., Stöffler D. and Eugster O. (2001) Ages and histories of martian meteorites. In Chronology and Evolution of Mars (eds. Kallenbach R., Geiss J. and Hartmann W. K.) Springer, pp. 105-164.

Nyquist L.E., Wiesmann, H., Bansal, B.M., Shih, C.-Y., Keith, J.E., Harper, C.L. (1995) ${ }^{146} \mathrm{Sm}-$ ${ }^{142} \mathrm{Nd}$ formation interval for the lunar mantle. Geochim. Cosmochim. Acta 59, 2817-2837.

Nyquist L. E., Wooden J., Bansal B. M., Wiesmann H., McKay G., and Bogard D. D. (1979) RbSr age of the Shergotty Achondrite and Implications for Metamorphic Resetting of Isochron Ages. Geochim. Cosmochim. Acta 43, 1057-1074.

Papanastassiou D. A. and Wasserburg G. J. (1969) Initial strontium isotopic abundances and the resolution of small time differences in the formation of planetary objects. Earth Planet. Sci. Lett. 5, 361-376.

Rankenburg K., Brandon A. D., and Neal C. R. (2006) Neodymium isotope evidence for a chondritic composition of the Moon. Science 312, 1369-1372.

Russ P. G., Burnett D. S., and Wasserburg, G. J. (1972) Lunar neutron stratigraphy. Earth Planet. Sci. Lett. 15, 172-186. 
Shearer C. K. and Righter K. (2003) Behavior of tungsten and hafnium in silicates: A crystal chemical basis for understanding the early evolution of the terrestrial planets. Geophys. Res. Lett. 30, 1-4.

Shih C. -Y., Nyquist L. E., Bogard D. D., McKay G. A., Wooden J. L., Bansal B. M., Wiesmann H. (1982) Chronology and Petrogenesis of Young Achondrites, Shergotty, Zagami, and ALHA 77005: Late Magmatism on a Geologically Active Planet. Geochim. Cosmochim. Acta 46, 2323-2344.

Snyder G. A., Taylor L. A., and Neal C. R. (1992) A chemical model for generating the sources of mare basalts: Combined equilibrium and fractional crystallization of the lunar magmasphere. Geochimica et Cosmochimica Acta 56:3809-3823.

Symes S. J. K., Borg L. E., Shearer C. K., and Irving A. J. (2008) The age of the martian meteorite Northwest Africa 1195 and the differentiation history of the shergottites. Geochim. Cosmochim. Acta.72, 1696-1710.

Tonks W. B. and Melosh H. J. (1993) Magma ocean formation due to giant impacts. J. Geophys. Res. 98, 5319-5333.

Wilheims D. E. and Squires S. W. (1984) The Martian hemispheric dichotomy may be due to a giant impact. Nature 309, 138-140.

Yoshino T. Walter M. J., and Katsura T. (2003) Core formation in planetismals triggered by permeable flow. Nature 422, 154-157.

Zipfel J., Scherer P., Spettel B., Dreibus G, and Schultz L. (2000) Petrology and chemistry of the new shergottite Dar al Gani 476. Meteor. Planet. Sci. 35, 95-106. 
Table 1. $\mathrm{Rb}, \mathrm{Sr}, \mathrm{Sm}$, and Nd concentration data

\begin{tabular}{|c|c|c|c|c|c|c|c|c|}
\hline $\begin{array}{l}\text { Sub- } \\
\text { group }\end{array}$ & Sample & $\begin{array}{l}\text { Weight } \\
\text { (g) }\end{array}$ & $\begin{array}{c}\mathrm{Rb} \\
(\mathrm{ppm})\end{array}$ & $\begin{array}{c}\mathrm{Sr} \\
(\mathrm{ppm})\end{array}$ & $\left(\frac{{ }^{87} R b}{{ }^{86} S r}\right)^{b}$ & $\begin{array}{c}\mathrm{Sm} \\
(\mathrm{ppm})\end{array}$ & $\begin{array}{c}\mathrm{Nd} \\
(\mathrm{ppm})\end{array}$ & $\left(\frac{{ }^{147} S m}{{ }^{144} N d}\right)^{c}$ \\
\hline \multirow{7}{*}{ 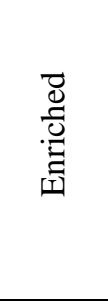 } & Los Angeles & 0.231 & & & & 2.161 & 5.576 & $0.23432 \pm 23$ \\
\hline & Dho 378 & 0.498 & 4.42 & 79.29 & $0.1612 \pm 16$ & 1.149 & 2.859 & $0.24301 \pm 24$ \\
\hline & NWA 856 & 0.207 & 5.19 & 41.99 & $0.3581 \pm 36$ & 0.9542 & 2.379 & $0.24247 \pm 24$ \\
\hline & NWA 4878 & 0.561 & 4.92 & 71.64 & $0.1989 \pm 20$ & 1.274 & 3.177 & $0.24245 \pm 24$ \\
\hline & NWA 1068 & 0.433 & 5.37 & 63.67 & $0.2441 \pm 21$ & 1.348 & 3.516 & $0.23182 \pm 23$ \\
\hline & NWA 4468 & 0.430 & & & & 0.7559 & 1.917 & $0.23835 \pm 24$ \\
\hline & NWA 4468 & 0.394 & 3.06 & 26.39 & $0.3360 \pm 33$ & 0.5306 & 1.301 & $0.24650 \pm 25$ \\
\hline \multirow{2}{*}{ 咅: } & EET79001A & 0.738 & 0.896 & 13.66 & $0.1898 \pm 19$ & 0.6183 & 0.892 & $0.41890 \pm 42$ \\
\hline & NWA 480 & 0.240 & 2.31 & 46.40 & $0.1440 \pm 14$ & 1.198 & 2.457 & $0.29478 \pm 29$ \\
\hline \multirow{4}{*}{$\frac{\frac{\vec{d}}{0}}{\frac{0}{0}}$} & $\mathrm{DaG} 476$ & 1.812 & 0.531 & 57.95 & $0.02652 \pm 27$ & 0.3659 & 0.425 & $0.51689 \pm 51$ \\
\hline & SaU 005 & 1.839 & 0.298 & 79.30 & $0.01089 \pm 11$ & 0.4387 & 0.540 & $0.49071 \pm 49$ \\
\hline & Tissint & 0.460 & 0.229 & 25.62 & $0.02590 \pm 26$ & 0.7159 & 1.116 & $0.38332 \pm 38$ \\
\hline & Dhofar $019^{a}$ & 0.016 & 0.652 & 307.1 & $0.00615 \pm 70$ & 0.6698 & 1.079 & $0.37534 \pm 38$ \\
\hline
\end{tabular}

${ }^{a}$ Isotope dilution measurement only.

${ }^{b .}$ Error limits apply to last digits and include a minimum uncertainty of $1 \%$ plus $50 \%$ of the blank correction for $\mathrm{Rb}$ and $\mathrm{Sr}$ added quadratically.

c. Error limits apply to last digits and include a minimum uncertainty of $0.1 \%$ plus $50 \%$ of the blank correction for Sm and $\mathrm{Nd}$ added quadratically. 
Table 2. Sr, Sm, and Nd Isotopic Data

\begin{tabular}{|c|c|c|c|c|c|c|c|c|}
\hline $\begin{array}{l}\text { Sub- } \\
\text { group }\end{array}$ & Sample & $\begin{array}{c}\text { Age } \\
\text { Sample } \\
(\mathrm{Ma})^{\mathrm{a}}\end{array}$ & $\left(\frac{{ }^{87} S r}{{ }^{86} S r}\right)^{d}$ & $\left(\frac{{ }^{143} N d}{{ }^{144} N d}\right)^{e}$ & $\left(\frac{{ }^{142} N d}{{ }^{144} N d}\right)^{e}$ & $\varepsilon_{N d}^{142}$ & $\left(\frac{{ }^{147} S m}{{ }^{144} N d}\right)^{f}$ & $\begin{array}{c}\text { Model } \\
\text { Age }(\mathrm{Ma})^{g}\end{array}$ \\
\hline \multirow{8}{*}{ 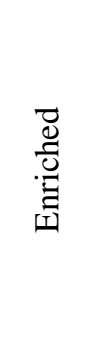 } & Los Angeles & 170 & & $0.512327 \pm 1$ & $1.141815 \pm 3$ & -0.20 & 0.1844 & $4530 \pm 23$ \\
\hline & Dho 378 & 157 & $0.720922 \pm 5$ & $0.512335 \pm 1$ & $1.141813 \pm 2$ & -0.21 & 0.1846 & $4549 \pm 17$ \\
\hline & NWA 856 & 170 & $0.723390 \pm 7$ & $0.512321 \pm 2$ & $1.141819 \pm 6$ & -0.16 & 0.1839 & $4475 \pm 61$ \\
\hline & NWA 4878 & 170 & $0.720626 \pm 6$ & $0.512331 \pm 1$ & $1.141817 \pm 2$ & -0.17 & 0.1842 & $4498 \pm 24$ \\
\hline & NWA 1068 & 185 & $0.717949 \pm 5$ & $0.512352 \pm 1$ & $1.141819 \pm 2$ & -0.16 & 0.1852 & $4493 \pm 23$ \\
\hline & NWA 4468 & 187 & & $0.512316 \pm 1$ & $1.141818 \pm 4$ & -0.17 & 0.1837 & $4485 \pm 39$ \\
\hline & NWA 4468 & 187 & $0.720852 \pm 5$ & $0.512323 \pm 1$ & $1.141818 \pm 3$ & -0.17 & 0.1836 & $4482 \pm 27$ \\
\hline & \multicolumn{2}{|c|}{ Average (2SD) } & & & & & & $4504 \pm 55$ \\
\hline \multirow{3}{*}{ 离 } & EET79001A & 173 & $0.712979 \pm 5$ & $0.513724 \pm 2$ & $1.141863 \pm 7$ & +0.23 & 0.2257 & $4507 \pm 36$ \\
\hline & NWA 480 & 343 & $0.709702 \pm 5$ & $0.513380 \pm 1$ & $1.141854 \pm 4$ & +0.15 & 0.2156 & $4522 \pm 26$ \\
\hline & \multicolumn{2}{|c|}{ Average (2SD) } & & & & & & $4515 \pm 23$ \\
\hline \multirow{5}{*}{$\frac{\frac{\vec{d}}{0}}{\frac{\overrightarrow{0}}{\Delta}}$} & $\mathrm{DaG} 476$ & 474 & $0.707158 \pm 6$ & $0.515516 \pm 1$ & $1.141911 \pm 4$ & +0.65 & 0.2670 & $4507 \pm 8$ \\
\hline & SaU 005 & 445 & $0.707034 \pm 5$ & $0.515324 \pm 1$ & $1.141902 \pm 3$ & +0.57 & 0.2645 & $4495 \pm 7$ \\
\hline & Tissint & 580 & $0.701039 \pm 7$ & $0.515506 \pm 1$ & $1.141920 \pm 3$ & +0.72 & 0.2794 & $4498 \pm 5$ \\
\hline & Dhofar $019^{c}$ & 574 & $0.707756 \pm 9$ & $0.515106 \pm 25$ & & & 0.2654 & \\
\hline & Ave, (2SD) & & & & & & & $4503 \pm 13$ \\
\hline
\end{tabular}

Shergottite Average (2SD)

$4504 \pm 42$

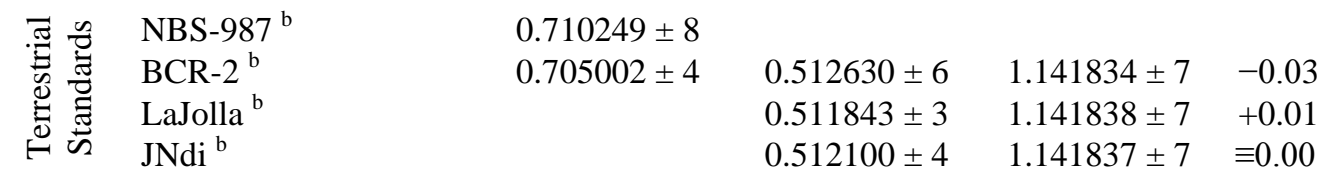

$\bar{a}$. Age of samples summarized in Nyquist et al. (2001), Borg and Drake (2005) and from Borg et al. (2001), Brennecka et al. (2014), and Marks et al. (2010).

b. Average values obtained on standards during the course of this investigation. Uncertainties refer to last digits and are $2 \sigma_{\mathrm{p}}(2 \mathrm{x}$ standard deviation of population of mass spectrometry runs on isotopic standard). NBS-987 standard average of $\mathrm{N}=55$ runs, BCR-2 standard average of $\mathrm{N}=13$ runs, JNdi standard average of $\mathrm{N}=52$ runs, LaJolla standard average of $\mathrm{N}=14$ runs.

c. Isotope dilution measurements only.

d. Measured value normalized to ${ }^{86} \mathrm{Sr} /{ }^{88} \mathrm{Sr}=0.1194$. Uncertainties refer to last digits and are $2 \sigma_{\mathrm{m}}(2 \mathrm{x}$ standard error of measured isotopic ratios)

e. Measured value normalized to ${ }^{146} \mathrm{Nd} /{ }^{144} \mathrm{Nd}=0.7219$. Uncertainties refer to last digits and are $2 \sigma_{\mathrm{m}}(2 \mathrm{x}$ standard error of measured isotopic ratios).

${ }^{\text {f. }}$ Value calculated from value equation 1.

g. Value calculated from Equation 2 assuming bulk Mars has present-day ${ }^{142} \mathrm{Nd} /{ }^{144} \mathrm{Nd}=1.141830$ (derived from the yaxis value in Fig. 2 at a $\left.{ }^{147} \mathrm{Sm} /{ }^{144} \mathrm{Nd}=0.1967\right)$. Uncertainties on individual model ages reflect the precision of the measured ${ }^{142} \mathrm{Nd} /{ }^{144} \mathrm{Nd}$ ratios, whereas the uncertainties on average model ages are $2 \times$ the standard deviation of respective ages 
Table 3. Samarium isotopic compositions

\begin{tabular}{|c|c|c|c|c|c|c|c|c|}
\hline $\begin{array}{l}\text { Sub- } \\
\text { group }\end{array}$ & Sample & $\left(\frac{{ }^{144} S m}{{ }^{152} S m}\right)$ & $\left(\frac{{ }^{148} S m}{{ }^{152} S m}\right)$ & $\left(\frac{{ }^{149} S m}{{ }^{152} S m}\right)$ & $\left(\frac{{ }^{150} S m}{{ }^{152} S m}\right)$ & $\left(\frac{{ }^{154} S m}{{ }^{152} S m}\right)$ & $\varepsilon_{S m}^{149}$ & $\varepsilon_{S m}^{150}$ \\
\hline \multirow{4}{*}{ 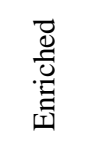 } & Los Angeles & $0.114977 \pm 2$ & $0.420437 \pm 2$ & $0.516847 \pm 2$ & $0.276002 \pm 2$ & $0.850798 \pm 4$ & -0.08 & +0.33 \\
\hline & NWA 856 & $0.114972 \pm 3$ & $0.420437 \pm 3$ & $0.516845 \pm 3$ & $0.275995 \pm 2$ & $0.850794 \pm 5$ & -0.12 & +0.07 \\
\hline & NWA 4878 & $0.114972 \pm 2$ & $0.420437 \pm 2$ & $0.516851 \pm 2$ & $0.275990 \pm 2$ & $0.850801 \pm 6$ & 0.00 & -0.11 \\
\hline & NWA 4468 & $0.114976 \pm 2$ & $0.420437 \pm 3$ & $0.516856 \pm 3$ & $0.275994 \pm 2$ & $0.850789 \pm 5$ & +0.10 & +0.04 \\
\hline \multirow{2}{*}{ 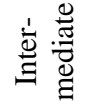 } & EET79001A & $0.114974 \pm 2$ & $0.420437 \pm 2$ & $0.516846 \pm 3$ & $0.275990 \pm 2$ & $0.850804 \pm 5$ & -0.10 & -0.11 \\
\hline & NWA 480 & $0.114971 \pm 2$ & $0.420436 \pm 2$ & $0.516848 \pm 3$ & $0.275990 \pm 1$ & $0.850803 \pm 3$ & -0.06 & -0.11 \\
\hline \multirow{3}{*}{$\frac{\overline{\frac{\pi}{0}}}{\frac{0}{2}}$} & $\mathrm{DaG} 476$ & $0.114974 \pm 2$ & $0.420440 \pm 3$ & $0.516846 \pm 3$ & $0.275992 \pm 2$ & $0.850801 \pm 5$ & -0.10 & -0.04 \\
\hline & $\mathrm{SaU} 005$ & $0.114973 \pm 2$ & $0.420437 \pm 2$ & $0.516849 \pm 2$ & $0.275991 \pm 1$ & $0.850799 \pm 4$ & -0.04 & -0.07 \\
\hline & Tissint & $0.114976 \pm 3$ & $0.420436 \pm 3$ & $0.516857 \pm 3$ & $0.275994 \pm 2$ & $0.850762 \pm 5$ & +0.12 & +0.04 \\
\hline \multirow{3}{*}{ 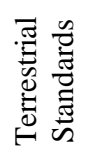 } & BCR-2 & $0.114975 \pm 2$ & $0.420438 \pm 6$ & $0.516851 \pm 3$ & $0.275992 \pm 2$ & $0.850795 \pm 7$ & 0.00 & -0.03 \\
\hline & BCR-2 & $0.114977 \pm 2$ & $0.420440 \pm 6$ & $0.516854 \pm 3$ & $0.275994 \pm 2$ & $0.850793 \pm 6$ & 0.06 & +0.04 \\
\hline & AMES $^{\text {a }}$ & $0.114976 \pm 7$ & $0.420438 \pm 8$ & $0.516851 \pm 8$ & $0.275993 \pm 3$ & $0.850798 \pm 9$ & $\equiv 0.00$ & $\equiv 0.00$ \\
\hline
\end{tabular}

Measured value normalized to ${ }^{147} \mathrm{Sm} /{ }^{152} \mathrm{Sm}=0.56801$. Uncertainties refer to last digits and are $2 \sigma_{\mathrm{m}}(2 \times$ standard error of measured isotopic ratios).

a. Average value obtained on AMES Sm standard $(\mathrm{N}=9)$ during the course of this investigation. Uncertainties refer to last digits and are $2 \sigma_{\mathrm{p}}(2 \times$ standard deviation of population of mass spectrometry runs on isotopic standard). 
Table 4. Variables used in equations 1-4

\begin{tabular}{|c|c|c|}
\hline Variable & Description & Value \\
\hline$\left({ }^{143} \mathrm{Nd} /{ }^{144} \mathrm{Nd}\right)^{\mathrm{M} 3}$ & Present-day whole rock Nd isotopic ratio & Measured \\
\hline$\left({ }^{142} \mathrm{Nd} /{ }^{144} \mathrm{Nd}\right)^{\mathrm{M} 2}$ & Present-day whole rock Nd isotopic ratio & Measured \\
\hline$\left({ }^{143} \mathrm{Nd} /{ }^{144} \mathrm{Nd}\right)^{\mathrm{SSI}}$ & Solar System initial Nd isotopic ratio & $0.506674^{\mathrm{a}}$ \\
\hline$\left({ }^{142} \mathrm{Nd} /{ }^{144} \mathrm{Nd}\right)^{\mathrm{B}}$ & Bulk Mars Nd isotopic composition & 1.141830 \\
\hline$\left({ }^{147} \mathrm{Sm} /{ }^{144} \mathrm{Nd}\right){ }^{\mathrm{Ch}}$ & $\begin{array}{l}\text { Present-day bulk planet ratio } \\
\text { (determined from analysis of chondritic meteorites) }\end{array}$ & $0.1967^{\mathrm{a}}$ \\
\hline$\left({ }^{147} \mathrm{Sm} /{ }^{144} \mathrm{Nd}\right)^{\mathrm{M} 1}$ & Present-day whole rock ratio & Measured \\
\hline$\left({ }^{146} \mathrm{Sm} /{ }^{144} \mathrm{Sm}\right){ }^{\mathrm{SSI}}$ & Solar System initial Sm isotopic composition & $0.00828^{b}$ \\
\hline $\mathrm{T}_{0}$ & Age of Solar System (determined from CAIs) & $4567 \mathrm{Ma}^{\mathrm{c}}$ \\
\hline $\mathrm{T}_{1}$ & Differentiation age of Mars & Solved for \\
\hline $\mathrm{T}_{2}$ & Internal isochron age of martian meteorite & Measured \\
\hline$\lambda^{147}$ & ${ }^{147}$ Sm decay constant & $6.54 \times 10^{-6} \mathrm{Ma}^{-1}$ \\
\hline$\lambda^{146}$ & ${ }^{146} \mathrm{Sm}$ decay constant & $0.0067296 \mathrm{Ma}^{-1 \mathrm{~b}}$ \\
\hline$\left({ }^{144} \mathrm{Sm} /{ }^{147} \mathrm{Sm}\right){ }^{\mathrm{Std}}$ & $\begin{array}{l}\text { Sm isotopic composition determined from terrestrial } \\
\text { standards }\end{array}$ & 0.202419 \\
\hline$\left({ }^{147} \mathrm{Sm} /{ }^{144} \mathrm{Nd}\right)^{\mathrm{S}}$ & $\begin{array}{l}\mathrm{Sm} / \mathrm{Nd} \text { isotopic composition of shergottite source } \\
\text { regions }\end{array}$ & Solved for \\
\hline$\left({ }^{142} \mathrm{Nd} /{ }^{144} \mathrm{Nd}\right)^{\mathrm{Calc}}$ & Value used as denominator for calculating $\varepsilon^{142} \mathrm{Nd}$ & 1.141837 \\
\hline$\left({ }^{143} \mathrm{Nd} /{ }^{144} \mathrm{Nd}\right){ }^{\mathrm{Calc}}$ & Value used as denominator for calculating $\varepsilon^{143} \mathrm{Nd}$ & 0.512638 \\
\hline
\end{tabular}

a. Jacobsen and Wasserburg (1980)

${ }^{\text {b. }}$ Marks et al. (2014a)

c. Amelin et al. (2010); Connelly et al. (2012) 
Table 5. Examples of Sm-Nd ages calculated using different methods

\begin{tabular}{lcccl}
\hline \multicolumn{1}{c}{ Sample } & $\begin{array}{c}{ }^{147} \mathrm{Sm}-{ }^{143} \mathrm{Nd} \\
\text { age }(\mathrm{Ma})\end{array}$ & $\begin{array}{c}{ }^{146} \mathrm{Sm}^{1}{ }^{142} \mathrm{Nd} \\
\text { age }(\mathrm{Ma})\end{array}$ & $\begin{array}{c}{ }^{142} \mathrm{Nd}-{ }^{143} \mathrm{Nd} \\
\text { age }(\mathrm{Ma})\end{array}$ & \multicolumn{1}{c}{ Reference } \\
\hline 60025 & $4367 \pm 15$ & $4318^{+30} /-38$ & $4319^{+30} /-38$ & Borg et al. (2011) \\
76535 & $4307 \pm 11$ & $4300^{+29} /-36$ & $4299^{+29} /-36$ & Borg et al. (2013) \\
60016 & $4300 \pm 32$ & $4298^{+57} /-94$ & $4296^{+58} /-97$ & Marks et al. (2014b) \\
77215 & $4283 \pm 23$ & $4348^{+59} /_{-100}$ & $4350^{+58} /-96$ & Carlson et al (2014) \\
CAI Al3S4 ${ }^{\mathrm{A}}$ & $4560 \pm 34$ & $4564^{+7.9} /-8.4$ & $4565^{+8.0} /-8.4$ & Marks et al. (2014a) \\
\hline
\end{tabular}

Ages calculated using ${ }^{146} \mathrm{Sm} \mathrm{t} \mathrm{t}_{2}=103 \mathrm{Ma}$ and ${ }^{146} \mathrm{Sm} /{ }^{144} \mathrm{Sm}=0.00828$ following Marks et al. (2014a). CAI A13S4 age calculated using ${ }^{146} \mathrm{Sm} /{ }^{144} \mathrm{Sm}=0.0084$ obtained from eucrite meteorites (Boyet et al., 2010). Slopes determined by regression of ${ }^{143} \mathrm{Nd} /{ }^{144} \mathrm{Nd}-{ }^{142} \mathrm{Nd} /{ }^{144} \mathrm{Nd}$ data are: $60025=0.0112 \pm 0.0025 ; 76535=0.098 \pm 0.0021 ; 60016=0.0096 \pm 0.0046 ; 77215=$ $0.0137 \pm 0.0065 ; \mathrm{CAI}$ Al3S $4=0.0561 \pm 0.0031$. 


\section{Figure Captions}

Figure 1. Plots of ${ }^{143} \mathrm{Nd} /{ }^{144} \mathrm{Nd}$ and ${ }^{142} \mathrm{Nd} /{ }^{144} \mathrm{Nd}$ versus age illustrating $\mathrm{Nd}$ evolution in three stages (circled numbers) as discussed in the text. Stage 1 is growth in an undifferentiated reservoir (represented by line between solid and open circles), stage 2 is growth in two differentiated reservoirs (dashed lines), and stage 3 represents growth in the meteorites after they solidified (solid lines). Present-day whole rock $\mathrm{Nd}$ isotopic values are represented by open squares, whereas initial ${ }^{143} \mathrm{Nd} /{ }^{144} \mathrm{Nd}$ ratios are represented by solid squares. The upper panel illustrates $\mathrm{Nd}$ growth curves for a depleted shergottite (Tissint; ${ }^{147} \mathrm{Sm} /{ }^{144} \mathrm{Nd}=0.2974$ ) and an enriched shergottite (NWA $4468 ;{ }^{147} \mathrm{Sm} /{ }^{144} \mathrm{Nd}=0.1836$ ) calculated using equation 1 assuming differentiation occurred at $4504 \mathrm{Ma}$ and bulk Mars had present-day ${ }^{147} \mathrm{Sm} /{ }^{144} \mathrm{Nd}=$ 0.1967 and ${ }^{143} \mathrm{Nd} /{ }^{144} \mathrm{Nd}=0.512638$ (Jacobsen and Wasserburg 1984). The thin dashed line represents growth in a reservoir that inherited the Solar System initial ${ }^{143} \mathrm{Nd} /{ }^{144} \mathrm{Nd}$ value assuming ${ }^{147} \mathrm{Sm} /{ }^{144} \mathrm{Nd}=0.1967$. This is a representation of growth in an undifferentiated reservoir with chondritic Sm-Nd isotopic systematics. Lower panel depicts growth of ${ }^{142} \mathrm{Nd} /{ }^{144} \mathrm{Nd}$ starting from a Solar System initial ${ }^{142} \mathrm{Nd} /{ }^{144} \mathrm{Nd}$ ratio measured in Allende CAI Al3S4 (Marks et al. 2014a). Growth of ${ }^{142} \mathrm{Nd} /{ }^{144} \mathrm{Nd}$ is modeled in two stages because ${ }^{146} \mathrm{Sm}$ is extinct before stage 3 begins. The ${ }^{142} \mathrm{Nd} /{ }^{144} \mathrm{Nd}$ isotopic composition of the undifferentiated reservoir at 4504 (open circle) is defined by the age and y-intercept of the ${ }^{146} \mathrm{Sm}^{-}{ }^{142} \mathrm{Nd}$ isochron from Figure 2. The undifferentiated present-day shergottite source (partially filled circle) is derived from the intersection of the whole rock ${ }^{142} \mathrm{Nd} /{ }^{144} \mathrm{Nd}^{143}{ }^{14 d}{ }^{142} \mathrm{Nd}$ isochron diagram (Figure 3) with the chondritic ${ }^{143} \mathrm{Nd} /{ }^{144} \mathrm{Nd}$ value of 0.512638 . A growth curve (thin dashed line) from the Solar System initial ${ }^{142} \mathrm{Nd} /{ }^{144} \mathrm{Nd}$ value defined by the CAI isochron of Marks et al (2014a) is within error of both the Nd isotopic composition defined for bulk Mars at $4504 \mathrm{Ma}$ and for the present-day from the ${ }^{146} \mathrm{Sm}-{ }^{142} \mathrm{Nd}$ (Figure 2) and ${ }^{143} \mathrm{Nd}-{ }^{142} \mathrm{Nd}$ isochrons (Figure 3).

Figure 2. $\mathrm{A}^{146} \mathrm{Sm}^{-142} \mathrm{Nd}$ isochron plot used to determine the age of formation of the shergottite source regions. Data from this study are open circles and data reported by Debaille et al. (2007) are filled squares. The measured bulk meteorite ${ }^{142} \mathrm{Nd} /{ }^{144} \mathrm{Nd}$ ratios are plotted versus the ${ }^{147} \mathrm{Sm} /{ }^{144} \mathrm{Nd}$ of martian meteorite source regions calculated from the measured ${ }^{143} \mathrm{Nd} /{ }^{144} \mathrm{Nd}$ ratios (Eq. 1). This isochron yields a ${ }^{146} \mathrm{Sm} /{ }^{147} \mathrm{Sm}$ slope of $0.001089 \pm$ $43(\mathrm{MSWD}=0.48)$ that corresponds to an age of $4503 \pm 6 \mathrm{Ma}(\mathrm{Eq} .3)$. Uncertainties plotted on diagram are internal uncertainties associated with the mass spectrometry measurements $\left(2 \sigma_{\mathrm{m}}\right)$, whereas uncertainty on the regression is calculated using two times the standard deviation of mass spectrometry runs on the standard $\left(2 \sigma_{p}\right)$. The uncertainty on the ${ }^{147} \mathrm{Sm} /{ }^{144} \mathrm{Nd}$ ratios is assumed to be $0.1 \%$. The initial ${ }^{142} \mathrm{Nd} /{ }^{144} \mathrm{Nd}$ of this isochron is $1.141615 \pm 8$, which corresponds to a present-day ${ }^{142} \mathrm{Nd} /{ }^{144} \mathrm{Nd}$ of 1.141830 , assuming bulk Mars has a ${ }^{147} \mathrm{Sm} /{ }^{144} \mathrm{Nd}$ similar to that of chondritic meteorites of 0.1967 , and the initial Solar System ${ }^{146} \mathrm{Sm} /{ }^{144} \mathrm{Sm}$ of $0.00828 \pm 43$ (Marks et al., 2014a). 
Figure 3. An $\varepsilon^{142} \mathrm{Nd}-\varepsilon^{143} \mathrm{Nd}$ isochron plot used to determine the age of formation of the shergottite source regions. The measured bulk meteorite $\varepsilon^{142} \mathrm{Nd}$ value is plotted against the $\varepsilon^{143} \mathrm{Nd}$ value of the present-day source region calculated from the initial ${ }^{143} \mathrm{Nd} /{ }^{144} \mathrm{Nd}$ of the meteorite. An isochron regressed through the data (thick solid line) yields a slope of 0.01636 \pm 52 (MSWD $=0.57$ ), which corresponds to an age of $4504 \pm 6 \mathrm{Ma}$ (Eq. 4b). A slope of $0.0364 \pm 0.0014$ is calculated from the regression of the ${ }^{142} \mathrm{Nd} /{ }^{144} \mathrm{Nd}-{ }^{143} \mathrm{Nd} /{ }^{144} \mathrm{Nd}$ plot. Vertical dashed lines are $\mathrm{Nd}$ isotopic growth curves calculated at different ages using ${ }^{147} \mathrm{Sm} /{ }^{144} \mathrm{Nd}$ of $0.17,0.1967,0.23,0.26$, and 0.29 . Thin solid lines are model isochrons calculated at common ages using different ${ }^{147} \mathrm{Sm} /{ }^{144} \mathrm{Nd}$ ratios. These isochrons are spaced at $50 \mathrm{Ma}$ intervals starting at $4200 \mathrm{Ma}$, excluding $4500 \mathrm{Ma}$, but including $4567 \mathrm{Ma}$. The present-day initial ${ }^{142} \mathrm{Nd} /{ }^{144} \mathrm{Nd}$ value determined by the y-intercept is $1.141830 \pm 2$ and is consistent with the value determined from Figure 2. The relationship of the present-day martian ${ }^{142} \mathrm{Nd} /{ }^{144} \mathrm{Nd}$ values to bulk Earth (open star) suggests that the $\mathrm{Nd}$ isotopic composition of Mars and Earth are very similar, and it remains possible that the shergottite source region represents a mixing relationship between the terrestrial $\mathrm{Nd}$ isotopic composition and the chondritic $\mathrm{Nd}$ isotopic composition. Chondritic $\mathrm{Nd}$ isotopic composition (solid star) is from Boyet and Carlson (2007).

Figure 4. $\mathrm{A} \mathrm{Rb}-\mathrm{Sr}$ isochron plot of shergottite whole rock data. Reference line has a slope corresponding to an age of $4.50 \mathrm{Ga}$ and passes through Basaltic Achondrite Best Initial (BABI) ${ }^{87} \mathrm{Sr} /{ }^{86} \mathrm{Sr}=0.69906$ (Papanastassiou and Wasserburg, 1969). Data from this study, Borg et al. (1997, 2001, 2002, 2003, 2005); Brennecka et al. (2014); Marks et al. (2010); Nyquist et al. (1979); and Symes et al. (2008). Samples from desert environments generally fall to the left and above reference line as a result of terrestrial weathering and addition of Sr.

Figure 5. A plot of ${ }^{147} \mathrm{Sm} /{ }^{144} \mathrm{Nd}$ measured in the bulk meteorite versus the ${ }^{147} \mathrm{Sm} /{ }^{144} \mathrm{Nd}$ calculated for the source region from the bulk rock ${ }^{143} \mathrm{Nd} /{ }^{144} \mathrm{Nd}$ using Equation 1. Solid line to the right of the 1:1 line is from Debaille et al. (2007) and was used to define the ${ }^{147} \mathrm{Sm} /{ }^{144} \mathrm{Nd}$ ratio of 0.159 for their enriched shergottite source region. The data are from this study, Borg et al. (1997, 2002, 2003, 2005); Brennecka et al. (2014); Caro et al. (2008); Debaille et al. (2007); and Shih et al. (1982); Symes et al. (2008) and fall to the right of the 1:1 line indicating the bulk meteorites are more depleted in light rare earth elements than their source regions. Note that these data do not define a linear array on this diagram indicating that compositional variation does not appear to reflect simple two-component mixing. Instead, several meteorites with variable ${ }^{147} \mathrm{Sm} /{ }^{144} \mathrm{Nd}$ ratios are derived from source regions with similar ${ }^{147} \mathrm{Sm} /{ }^{144} \mathrm{Nd}$ ratios suggesting that bulk rock chemistry is not related to long-term fractionation of $\mathrm{Sm} / \mathrm{Nd}$ in the source regions. 
Figure 6. A schematic illustration of the early evolution of Mars. The petrogenetic models are based on: (1) silicate differentiation of the shergottites source regions occurring at $4504 \pm 6$ Ma and (2) thermal modeling that suggest magma ocean solidification occurred rapidly after accretion terminated (Elkins-Tanton, 2008). Option 1 depicts rapid accretion and rapid early cooling of the martian magma ocean. It does not account for the young age of silicate differentiation determined for the shergottite source regions, nor provide an obvious mechanism to preserve ${ }^{182} \mathrm{~W}$ isotopic differences between various martian meteorites. Option 2 depicts a prolonged period of accretion that is sufficient to extend the period of cooling of some portions of the martian mantle until $4504 \mathrm{Ma}$. Option 3 depicts rapid initial accretion and magma ocean cooling followed by a giant impact. In this case the silicate differentiation age recorded in the shergottites reflects cooling of a portion of the mantle following melting by the impact event. Both options 2 and 3 imply significant accretion on Mars for $\sim 60 \mathrm{Ma}$. 


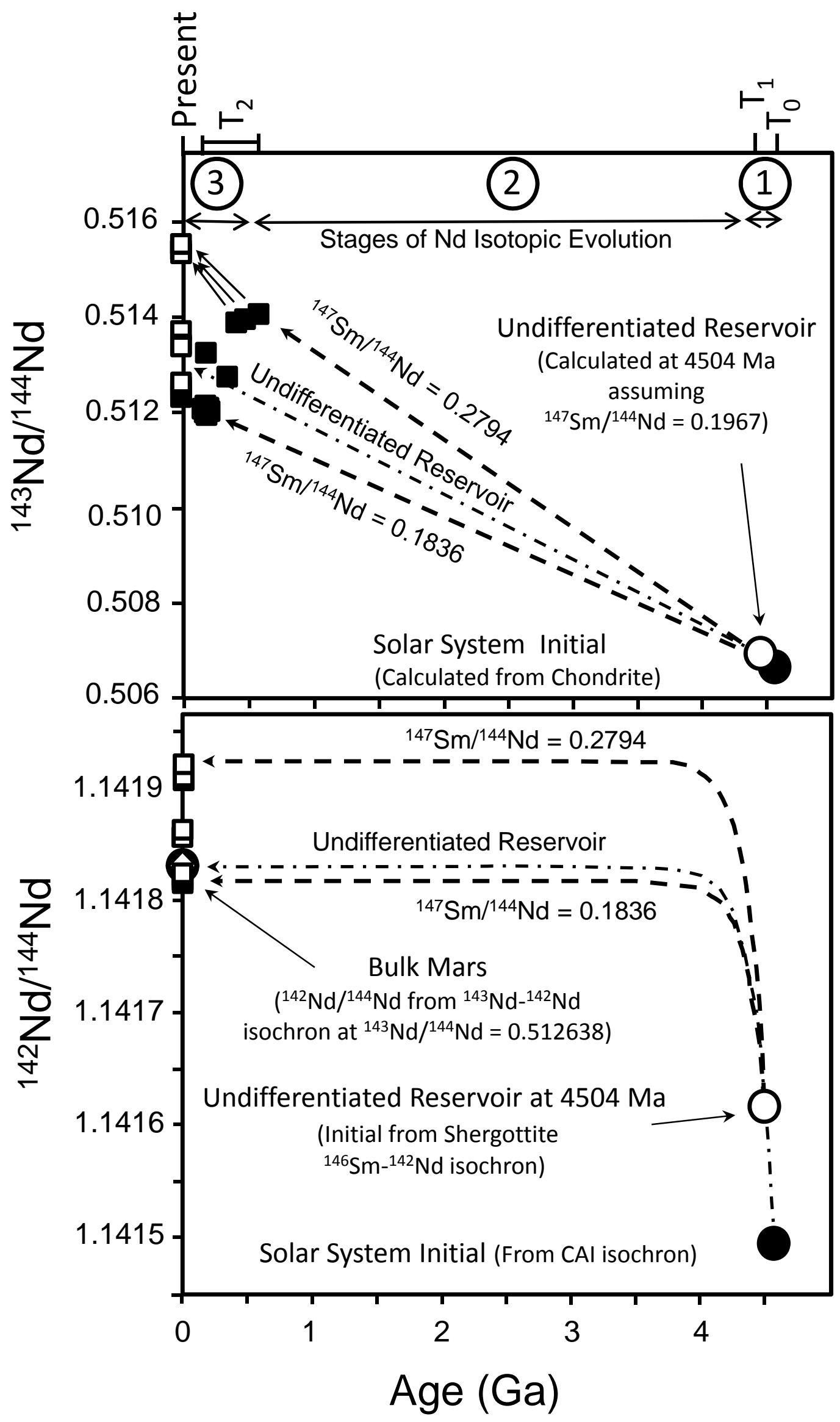




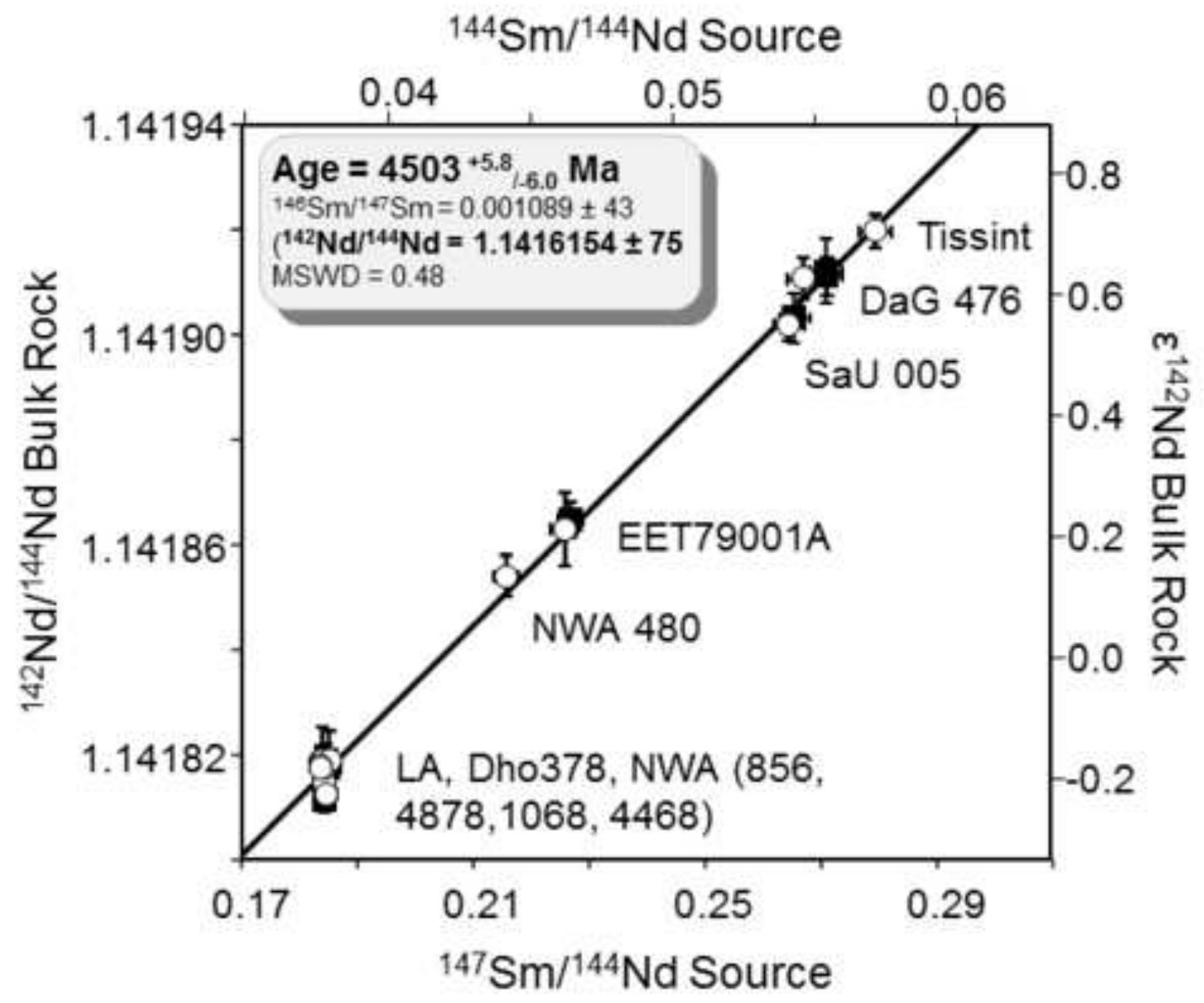

Figure 2 


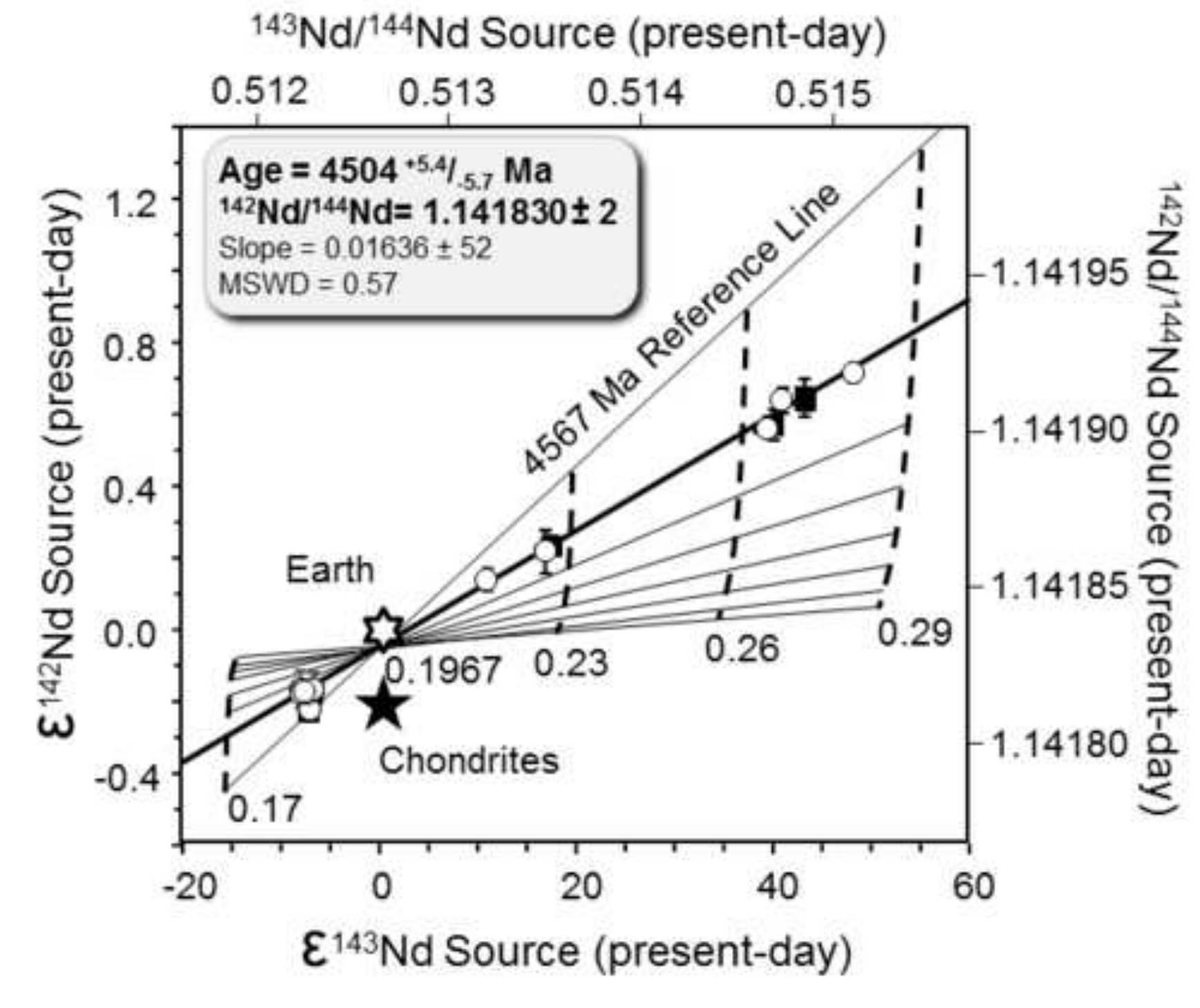

${ }^{143} \mathrm{Nd} /{ }^{144} \mathrm{Nd}$ Source (present-day)

(1) 


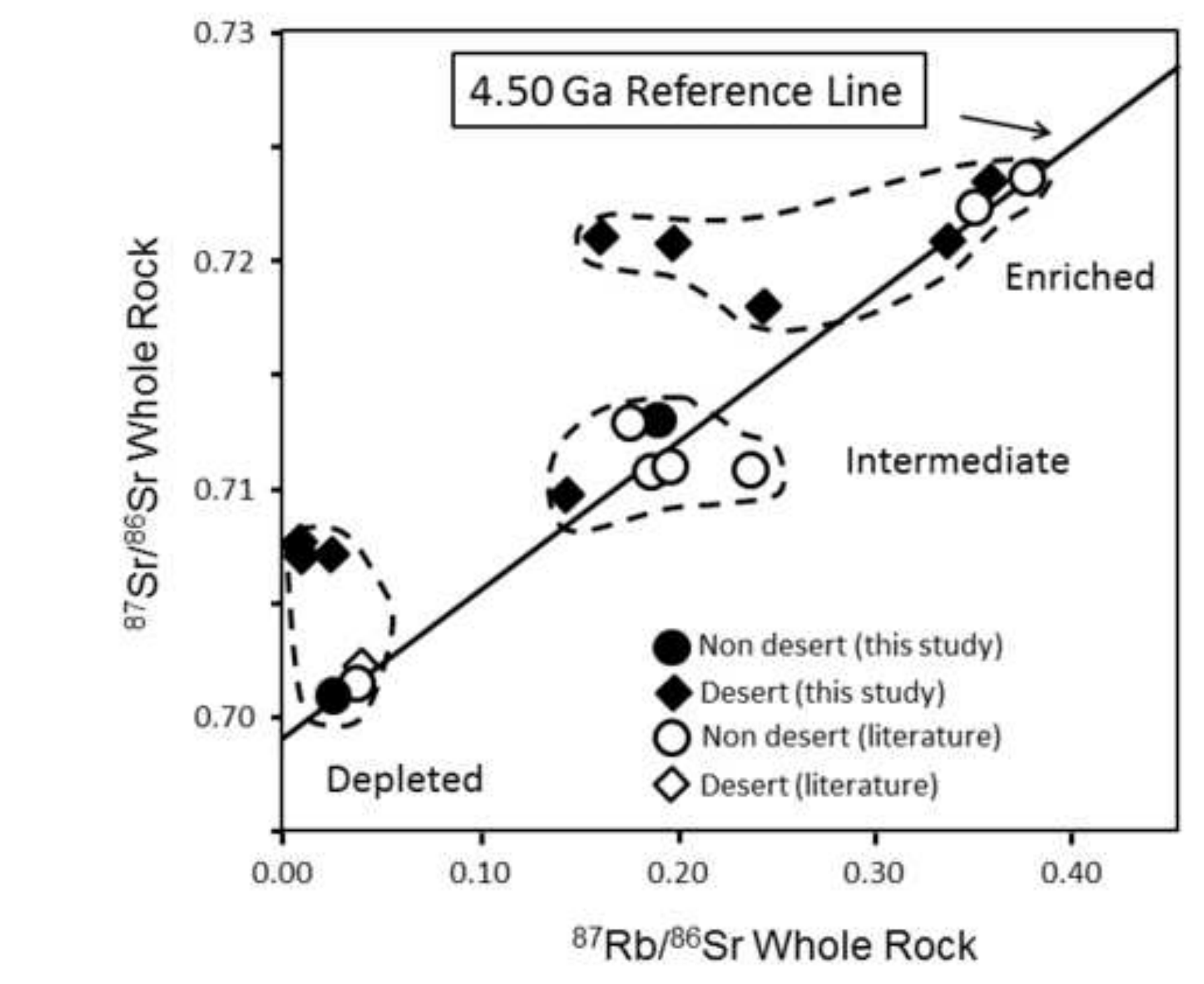

Figure 4

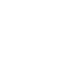

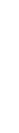

.




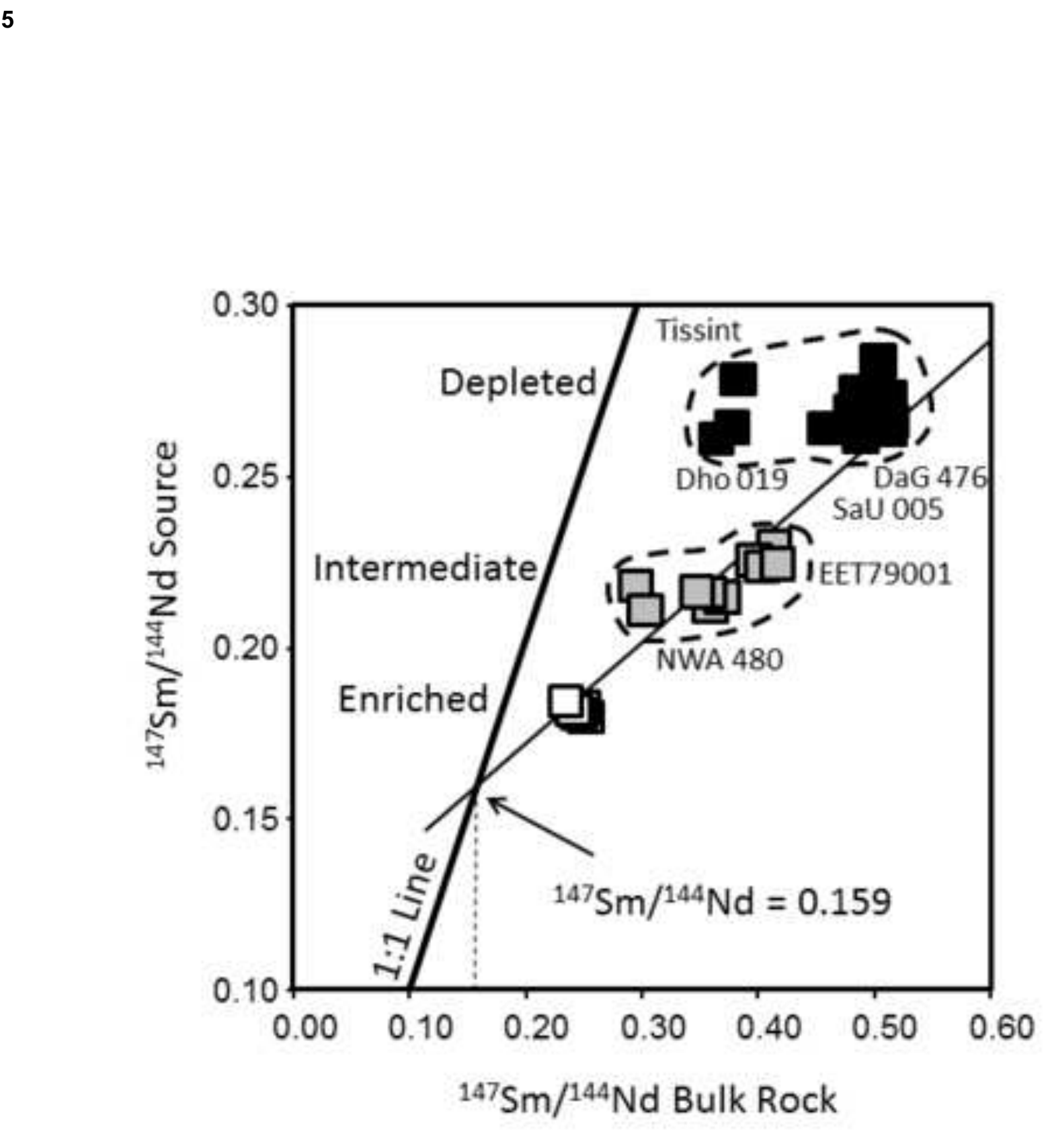

Figure 5

列
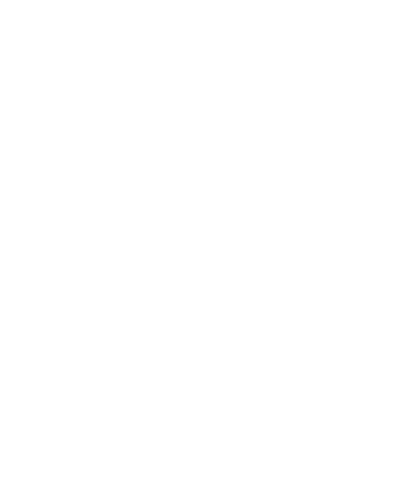


\section{Time}

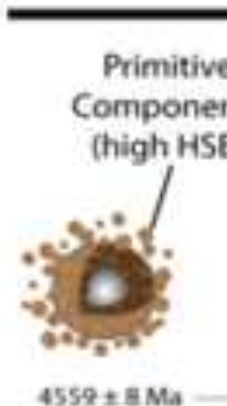

Rapid/early accretion and core formation
Planetary Core

(very high HSE)

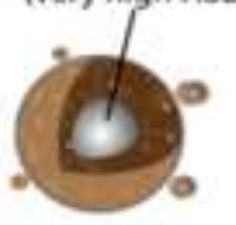

Slow cooling and very minor addition of material

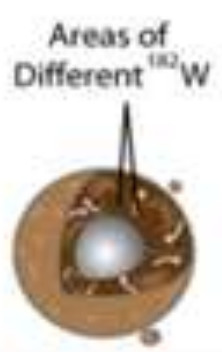

Separate

Nahklite/Shergottite

Source Regions

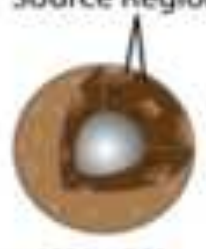

$4504+5 \mathrm{Ma}$
Option 1

Does not satisfy cooling models or HSE requirements

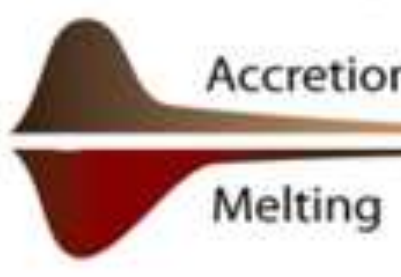

Silicate differentiation

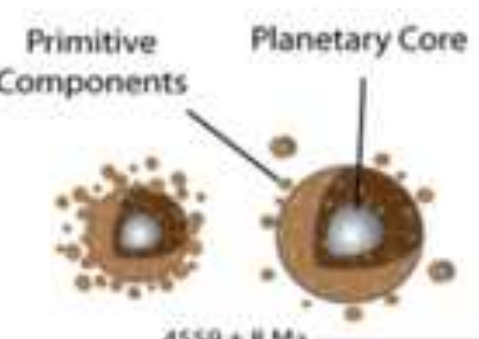

(x)

Early accretion and core formation

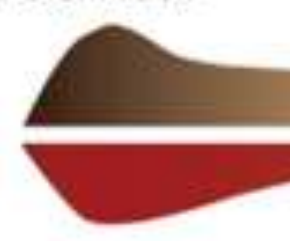

Protracted accretion producing variable ${ }^{17} \mathrm{~W}$
Separate

Metal/Silicate Segregation

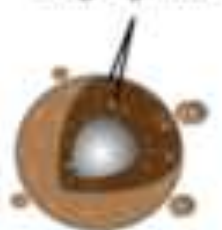

Accretion

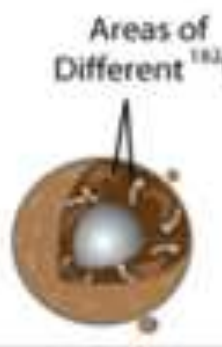

$-4504 \pm 5 \mathrm{Ma}$

Silicate differentiation and preservation of mantle hetergeneity

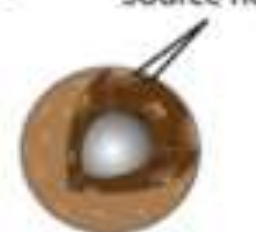

2.
Option 2

\section{Satisfies
cooling models
and HSE requirements \\ Satisfies
cooling models
and HSE requirements \\ Satisfies
cooling models
and HSE requirements}

Melting

Primitive Components

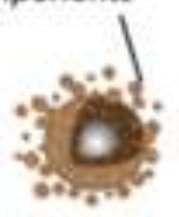

$4559 \pm 8 \mathrm{Ma}$
Planetary Core

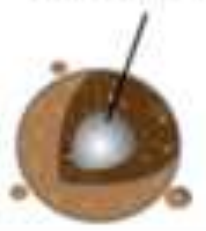

Rapid cooling followed by very minor addition of material
Significant impactor melts a major portion of the mantle

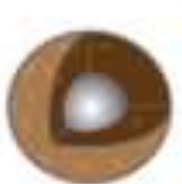

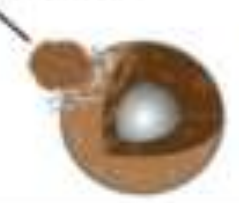

Rapid/early accretion and core formation

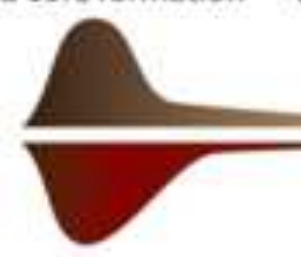

Accretion

Melting

Impact melting of a large portion of the mantle followed by silicate differentiation

\section{Option 3}

\author{
Satisfies \\ cooling models \\ and HSE requirements
}

